\title{
“As Isis Loved Osiris, So Let Matrona Love Theodoros...”: Sympathetic Magic and Similia Similibus Formulae in Greek and Latin Curse Tablets (Part 2)*
}

\author{
Juraj Franek \\ Czech Academy of Sciences, Centre for Classical Studies at the Institute of Philosophy \\ Na Florenci 1420/3, 11000 Prague 1, Czech Republic; franek@ics.cas.cz \\ Masaryk University, Department of Classical Studies \\ Arna Nováka 1/1, 60200 Brno, Czech Republic; j.franek@mail.muni.cz
}

\section{Daniela Urbanová}

Masaryk University, Department of Classical Studies

Arna Nováka 1/1, 60200 Brno, Czech Republic; urbanova@phil.muni.cz

For citation: Juraj Franek, Daniela Urbanová. “As Isis Loved Osiris, So Let Matrona Love Theodoros...”: Sympathetic Magic and Similia Similibus Formulae in Greek and Latin Curse Tablets (Part 2). Philologia Classica 2019, 14 (2), 177-207. https://doi.org/10.21638/11701/spbu20.2019.202

\begin{abstract}
In this contribution, we present a representative corpus of similia similibus formulae attested in ancient Greek and Latin curse tablets or defixiones. The simile formulae, attested in about 80 tablets in widely differing states of preservation and legibility, are introduced in the context of sympathetic magic and, in contradistinction to literary similes, as performative utterances that are based on a persuasive analogy. This analogy operates in the general form of "just as $\mathrm{X}$ possesses property $\mathrm{P}$, so let also $\mathrm{Y}$ possess property $\mathrm{P}$ ", in which $\mathrm{Y}$ is the target or victim of the curse, while $\mathrm{X}$ and $\mathrm{P}$ are variables that change in accordance with the intended results. We provide a provisional taxonomy of simile formulae, offer new readings and interpretations of some defixiones, and compare Greek and Latin documents. Due to its length, the paper has been divided into two parts. In the first part, presented in the previous issue of Philologia Classica (Vol. 14, Fasc. 1, Pp. 27-55), we introduced curse tablets, briefly discussed the principles of sympathetic magic, and focused on comparata that reference the materiality of the tablet and comparata referencing corpses or ghosts of the dead. The remaining comparata, namely animals, historiolae and rituals, aversus formulae and unusual orientations of the script, "names", and drawings, are presented in here together with general conclusions.
\end{abstract}

Keywords: curse tablets, defixiones, ancient magic, sympathetic magic, Greek and Latin epigraphy, similia similibus, simile formula, animals in antiquity, historiola.

\section{Animals}

Animals or animal parts were often used in ancient magical practices, either as sacrifices or as ingredients for various healing or harming recipes. ${ }^{1}$ In four curse tablets, an-

* The authors would like to express their gratitude to the two anonymous reviewers for the very helpful comments and suggestions they provided and to Elena Zheltova, Editor-in-Chief of Philologia Classica, for her extraordinarily constructive attitude in accommodating a prohibitively long original draft by allowing us to publish it in two parts. Daniela Urbanová kindly acknowledges the support of the Commission

(C) St. Petersburg State University, 2019 
imals appear as the comparatum of simile formulae. These animals were presumably manipulated in various ways (bound, killed, or mutilated) during the accompanying ritual, and the restrictive action performed on the animal was supposed to be transferred to the target of the curse. In a Greek agonistic curse tablet from Carthage, dated to the 1st-3rd cent. CE, ${ }^{2}$ a rooster's wings, feet, and head are bound; the same fate should befall a certain Victoricus and he should thereby lose a chariot race (in addition to Victoricus, the curse was also directed at all of the horses on his team).

(33) DT 241 (TheDeMa 60)

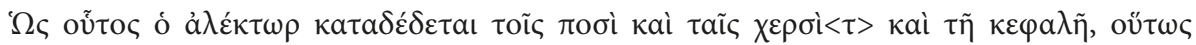

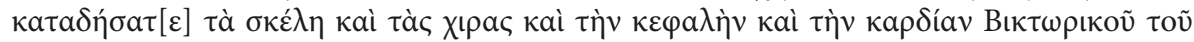

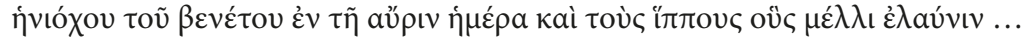

"Just as this rooster has been bound by its feet, hands, and head, so bind the legs and hands and head and heart of Victoricus the charioteer of the Blue team, for tomorrow; and also (bind) the horses which he is about to race ..." (transl. Gager)

In this case, just as in the Latin ones included below, it seems clear that the animal is used not as a sacrifice, but rather as a "living" voodoo doll or kolossos since any action performed on the animal should be transferred to the victim. ${ }^{3}$ Armand Delatte noted that another lamella found at the same location, unfortunately badly damaged, contained a drawn head of the rooster alongside proper names (undoubtedly the names of charioteers and/or horses), ${ }^{4}$ which would suggest a sustained use of roosters in agonistic magic at Carthage.

That the use of roosters in magical practice is not limited to agonistic contexts is supported by a Latin curse also from Carthage, found in an urn in a grave and dated to the 2nd-3rd cent. CE. ${ }^{5}$ This curse (like the remaining two in this section) is a curse in a legal context and the action performed on the rooster - tearing out its tongue and piercing it (presumably with a nail) - is to be replicated on the enemy in court, making him mute and unable to testify. ${ }^{6}$

for Ancient History and Epigraphy in Munich (Deutsches Archäologisches Institut), and especially its Vice Director Prof. Dr. Rudolf Haensch, for the opportunity to work on the paper as an invited research fellow in September 2019. This study is a result of the project GA ČR 19-02741S "The Transmission and Transformation of Ideas in Hellenism, Early Judaism, and Early Christianity" funded by the Czech Science Foundation.

1 This use is well-attested in Greek magical papyri as well; see Salayová 2017 for an overview.

2 Gager 1992, 65, No. 12; Tremel 2004, 167, No. 60.

3 On the use of animals as kolossoi, see Tremel 2004: 50-51, citing this Greek rooster defixio, or Ogden 2014, 301, who explicitly mentioned the puppy defixio (see (35) below).

${ }^{4}$ Delatte 1888, 295. On the next page (296), Delatte concluded (without any argument or supporting evidence) that the rooster had been "burned". Wünsch 1912, 12 argued that the formula must have been

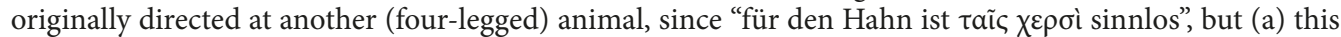
might possibly refer to wings, or (b) the writer might have had the physical constitution of the victim, Victoricus, rather than the medium, the rooster, in mind, which would account for this anatomical shortcoming.

5 The curse is inscribed on both sides of the tablet: side A contains the names of adversaries in a lawsuit, side B has the text of the curse itself, the end of which is, unfortunately, very damaged (for the emendations, see DT 222 and DFX 11.11/8).

${ }^{6}$ On "silencing" opponents in the context of legal curses, see Scholz 2011, 309-314. 
(Quomodo) huic gallo[...] lingua $(m)$ vivo extorsi et defixi, sic inimicorum meorum linguas adversus me ommutescant.

"Just as I ripped out and transfixed the tongue of this rooster while he was alive, so may the tongues of my enemies be equally struck mute against me...”.

Roosters are the third-most-mentioned animal in magical papyri - the recipes sometimes make use of specific parts (e.g. the head); when the entire rooster is to be used, it must be white. ${ }^{7}$ The PGM, however, do not provide any parallels to an aggressive magical ritual as described in the previous two curses. A very distant parallel, which might, however, reflect a much older ritual practice, may be found in cabalistic curses - as a curious aside, we may mention an instruction for an aggressive magical ritual involving a white rooster that was used in the 20th century as one of the many attempts to kill Adolf Hitler. ${ }^{8}$ Another Latin curse, found in Chagnon (Gaul) and dated to the 2nd cent. CE, transfers the qualities of a puppy, such as harmlessness and defencelessness, to the writer's opponents.

(35) DT 111-112 (TheDeMa 190, DFX 4.3.1/1-2, LCT 67-68)

Quomodo hic catellus nemin(i) nocuit, sic[...] nec illi hanc litem vincere possint; quomodi nec mater huius catelli defendere potuit, sic nec advocati eorum eos defendere \{non\} possint [...] Sic tra(n)specti ${ }^{9}$ sint quomodi ille. Quomodi in hoc m(o)nimont(o) (=monumento) animalia ommutuerun(t) nec surgere possun(t) nec illi mut(i?) [voces magicae].

"Just as this puppy harmed no one, so [may they harm no one?] ${ }^{10}$ and may they not be able to win this suit. Just as not even the mother of this puppy can defend [it], so may their lawyers be unable to defend them ... May they be pierced through, just as this [puppy is]. Just as in this tomb all [living] creatures have been silenced and cannot rise up, so may they not [be able to speak? or rise up]..."

Dogs are also mentioned in magical papyri as sacrifices and ingredients (e.g. the blood of a dog), but not as often as roosters are. ${ }^{11}$ The ultimate fate of the puppy is unknown, but it is reasonable to assume that it was killed during the ritual, especially given the Latin sic transpecti quomodo ille. The important difference with the two previous examples lies in the fact that the similes cited here - quomodo catellus nemin(i) nocuit; nec mater huius catelli defendere potuit; sic tra(n)specti sint (with the first part elliptically omitted); and, finally, quomodi animalia ommutuerun $(t)$-, do not only mirror the action that is performed on the animal, but also use its "natural" qualities as the basis for the persuasive analogy,

7 See PGM II, 1-64; PGM IV, 26-51; PGM IV, 2359-72; PGM XII, 14-95; PGM XII, 201-69; PGM XCIII, 7-21; PGM XII, 270-350; PGM XIII, 343-646; PGM XIII, 646-734; PGM XIII, 1-343; PGM IV, 2145-2240; PGM III, 633-731; PGM II, 64-183; and Salayová 2017, 199.

8 Harari 2017, 194-199. The prescription required the cursing party to buy a white rooster, name it after the enemy (i. e. the target of the future spell), then raise the rooster for 21 days, and, finally, slaughter it while saying seven times "As I slaughter this rooster, so will NN (the enemy) be slaughtered".

9 Transpecti, i.e. transpicti, is probably a mistake instead of the Classical Latin transfixi.

10 This is how Gager 1992, No. 53 filled in the lacuna.

11 PGM IV, 2622-2707; PGM XIa. 1-40; PDM Suppl. 138-149; PGM XIII.1-343; PGM IV, 27852890; cf. Salayová 2017, 196; for the connections of dogs to the underworld (Pluto, Proserpine, Hecate) and death, see Tonynbee 1996, 123. 
since a puppy, even a living one, was and is considered the epitome of harmlessness (but note also simile (50)) with its aversus formula on this very tablet below. Our last example of the use of animals in simile formulae comes from Peñaflor (Hispania). It was found in the soil of an ancient cemetery and dated to the 1 st cent. BCE. ${ }^{12}$

(36) Stylow 2012 \& 2014

Marcel(l)us Valerius mutus tacitus siet adversus C. Licinio Gallo. Qu(em)admodum rana sene (=sine) lingua muta et tacita est, sic Marcellus mutus tacitus, debilitus siet adv(e)rsus L(i)cinio Gallo.

"Marcellus Valerius, may he be mute silent against C. Licinius Gallus. As a frog without tongue is mute and silent, so may Marcellus be mute and silent, unable [to act in a lawsuit] against Licinius Gallus." (transl. Stylow, modified)

Plinius informs us about the magical properties of the frog and especially its tongue, which supposedly can be applied to that part of the body of a woman where the heartbeat is felt and the woman will answer any question truthfully. ${ }^{13}$ As in the previous examples, frog ingredients (including the tongue, recommended twice) are also mentioned in magical papyri. ${ }^{14}$ Since in antiquity frogs had the reputation of an animal that emitted disagreeable loud sounds and was even reported to have driven people out of their homeland, ${ }^{15}$ a croaking frog may be a fitting symbolic token for eloquent legal rivals and the removal of the animal's tongue, which can reasonably be expected to have formed part of the accompanying ritual, clearly served to make the opponents mute in court. ${ }^{16}$

\section{Historiola and ritual}

Several curse tablets allude to mythological themes with a simile formula that contains a comparatum concerning deities and their cults. It has been argued, and quite rightly so, that the simile formula "is inherent in the use of the historiola-whether or not the spell actually employs such a formula as 'as it was then, so may it be now"' ${ }^{17}$ We will, however, focus only on cases where the simile formula is not only implied, but even explicitly stated. One of the oldest preserved examples is a heavily damaged curse from Aegina (5th to 4 th cent. BCE):

(37) IG IV 2, 1012 (TheDeMa 423) $^{18}$

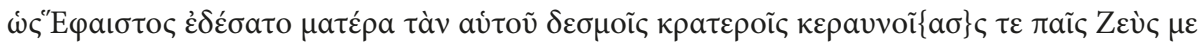

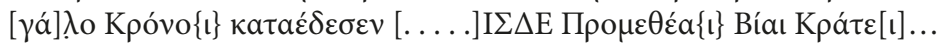

12 See Stylow 2012, 151, based on linguistic features and palaeography.

13 Plin. HN 32, 18.

14 See PGM V, 172-212; PDM XIV, 1-92; PGM XXXVI, 320-32; PGM XXXVI, 231-55; PGM X, 36-50. There are no direct parallels to the manipulation described on the tablet; see also the spell cited in note 79 below and simile (59), which uses a frog's tongue.

15 Kitchell 2014, 72-73.

16 Another ritual to silence evil tongues is attested by Ov. Fast. 2, 581: hostiles linguas inimicaque vinximus ora ("we have bound fast hostile tongues and unfriendly mouths", transl. J. G. Frazer).

17 Waller 2015, 267. On historiolae, see also Frankfurter 1995.

18 TheDeMa prints the older reading of SEG 57:313. 
"Just as Hephaestus bound his own mother with strong shackles and Zeus, son of great

Kronos, bound with thunderbolts ... Prometheus with Bia and Kratos ..."

Even though no oư $\tau \omega \varsigma$-clause is directly attested (the text is barely legible beyond the quoted part), it can, in our opinion, safely be concluded that the curse continued with the obligatory variation "... so let my opponents and enemies be bound as well". The author of the curse seems to be drawing allusions to two mythological episodes, one touching upon the story of Hephaestus binding Hera, ${ }^{19}$ the other on the well-known episode of the binding of Prometheus. ${ }^{20}$ Jumping almost one thousand years, two Greek defixiones from the 2nd-4th cent. CE use Egyptian and Jewish mythological stock to conjure the desired parallels between divinities and the curse victims. A love spell (å $\gamma \omega \gamma \eta \dot{)})$ from Oxyrrhynchus, written on a clay vessel with ink, and thus one of a handful of defixiones not written on thin lead sheets, alludes to the love of Isis and Osiris to create a similar emotional bond between Theodoros and Matrona:

(38) SupplMag 51 (TheDeMa 111)

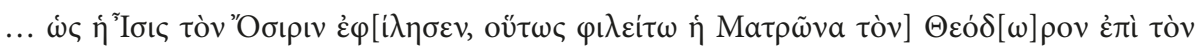

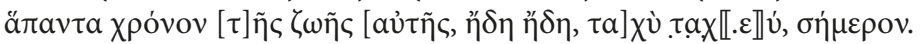

“... as Isis loved Osiris, so let Matrona love Theodoros for the entire time of her life, now now, quickly, quickly, today." (transl. Daniel — Maltomini)

The choice of the Osiris and Isis myth to serve as the basis for this historiola seems to be uniquely appropriate not only because "the love of Isis and Osiris was considered to be paragon model for every earthly love", 21 but also because of the connection of Osiris with the realm of death. ${ }^{22}$ Moreover, the curse seems to be following a magical prescription in which the love of Osiris and Isis is directly mentioned, and runs as follows: "I say to you, womb of NN, open and receive the seed of $\mathrm{NN}$ and the uncontrollable seed of the IARPHE ARPHE (write it). Let her, NN, love me for all her life as Isis loved Osiris and let her remain chase for me as Penelope did of Odysseus." ${ }^{23}$ Another, non-specific curse from Antiochia, dated to the 3rd to 4th cent. CE, has been written against a greengrocer named Babylas, probably in the context of a marketplace rivalry. ${ }^{24}$

(39) Hollmann 2011 (TheDeMa 376)

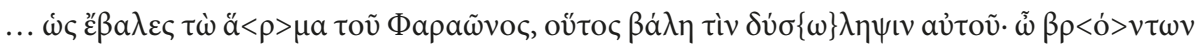

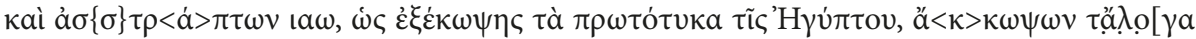

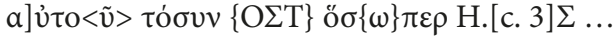

“... As you struck the chariot of Pharaoh, so strike his [Babylas'] offensiveness. O thunderand lightning-hurling Iao, as you cut down the firstborn of Egypt, cut down his [livestock?] as much as ..." (transl. Hollmann)

19 See, e.g., Paus. 1, 20, 3

20 See, canonically, Aesch. PV. For a concise overview of the Zeus-Prometheus mythology, see Hard 2004, 92-97.

21 As Wortmann 1968, 84 laconically noted in his commentary on this love spell.

${ }^{22}$ See, e.g., Assmann 2005, 23-38. The popularity of Isis and Osiris in the Hellenistic and Roman era is well known; on Isis and Osiris in Plutarch and Apuleius, see Griffiths 1970 and Griffiths 1975, respectively.

${ }^{23}$ PGM XXXVI, 283-94. The English translation is that of Betz 1986, 276.

${ }^{24}$ Kalleres 2015, 45-46. 
Both episodes clearly make use of Exodus material, ${ }^{25}$ but it must be added that the curse also contains another simile formula, which is most likely using the lead tablet itself as the comparatum, although it does not mention the tablet or any physical material directly. On the verso side, we read "just as you drown and will chill [this tablet] in the disused well, so too drown and chill the soul of Babylas, whom Dionysia, also known as Hesykhia, gave birth to, weighed down with illness and useless wherever he will be, and

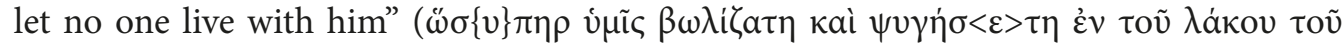

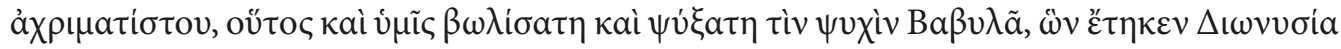

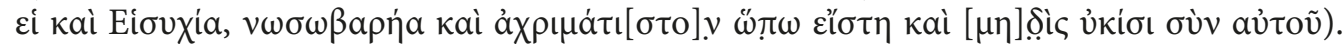
Alexander Hollmann noted that "no subject of the verbs $\beta \omega \lambda i \zeta \alpha \tau \eta$ and $\psi v \gamma \gamma \eta \dot{\sigma} \sigma<\varepsilon>\tau \eta$ is expressed, but it is presumably the lead", 26 a conclusion supported by (1), (2) and (3) in our corpus, where the lead (tablet) itself is termed "cold" ( $\psi v \chi \rho o$ ó, compare with $\psi v \gamma \eta \dot{\eta} \sigma<\varepsilon>\tau \eta$

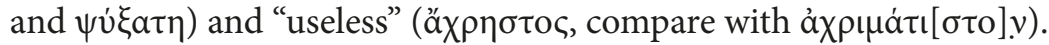

Latin curses with a simile formula containing a historiola or a reference to cultic practices are attested from Italy, Raetia, and especially Germania. Except for the separation curse from Rome (containing similes (41) and (42)), all of them are prayers for justice dated to the $1^{\text {st }}-2^{\text {nd }}$ cent. CE that mention theft or fraud (cf. sustulit (40); sustulit, fraudarunt (43), dolum malum (44), fraudem fecit (45); mandata exagatis (46)). They refer to various mythological entities, such as Virga (41) or Circe and Sirens (42). Four complicated texts found at the sanctuary of Magna Mater in Mogontiacum (Mainz) refer to the self-harm practiced by the Galli, her priests $(\mathbf{4 3}, \mathbf{4 4}, 45,46) .{ }^{27}$ In a prayer for justice from Veldidena (modern Wilten, Austria), the thief Cacus should punish the culprit of a robbery:

(40) DFX 7.5/1 (TheDeMa 109, LCT 238)

Secundina Mercurio et Moltino mandat, ut, si quis ${ }^{*}$ (denarios) XIIII sive draucus (=draucos?) duos sustulit, ut eum sive fortunas eius in(fi)dus Cacus sic auferat, quomodo ill(a)e ablatum est (i)d, quod vobis delegat, ut B: persecuatis (=persequatis) vobisque deligat, ut persicuatis (=persequatis) et eum aversum a fortunis (s)uis avertatis et a suis proxsimis et ab eis, quos carissimos (h)abeat...

"Secundina commands of Mercurius and Moltinus, concerning whoever has stolen two necklaces worth fourteen denarii, ${ }^{28}$ that deceitful Cacus remove him and his fortune, just as hers were taken, the very things which she hands over to you so that you will track them down. She hands them over to you so that you will track him down and separate him from his fortune, from his family and from his dear ones." (transl. Gager)

25 Regarding the destruction of the Pharaoh's chariots, see Ex. 14:23-28; regarding the destruction of Egypt's firstborn, see Ex. 12:29. As Hollmann 2011, 161 observed, the language of the tablet is closer to the hymnic reworkings of these themes (the Septuagint version of the "Song of the Sea", Ex. 15:4.1 in the case of the chariots and Ps. 134.8 in the case of the firstborn).

${ }^{26}$ Hollmann 2011, 164. Hollmann refers to Jordan 1985a for analogies (we discuss these below), but those concern onomata, and not the lead.

27 On this peculiar cultic practice and our tablets, see further esp. Gordon 2012, 198-204 and Dubosson-Sbriglione 2018, 139-140.

28 This is the interpretation of Gager 1992, No. 101; Versnel 1991, 83, n. 121 associated the word draucus with draukion, a Greek term for necklace. Another option for the translation of the text is "fourteen denarii and/or two necklaces"; regarding this interpretation, see Versnel 1991, 83 and Franz 1959, 69; Moltinus probably refers to a Celtic deity; cf. Egger 1964. 
The author, a woman named Secundia, seems to add the historiola to amplify the effect of the curse by ordering Mercurius and Moltinus to instruct Cacus, himself a notorious thief, ${ }^{29}$ to seek revenge for her stolen necklaces. Just as Cacus deprived Heracles of his flock, so should he also "separate [the thief] from this fortune, from his family and from his dear ones".

A curse from Rome, found near Via Ostiense in 2003, published in 2009 by G. Bevilacqua and O. Colacicchi, and dated to the 1st cent. CE, contains an extensive text of a spell directed against a Caecilia Prima, most likely in the context of a rivalry in love. This woman should die a terrible death that will be inflicted upon her by various infernal powers detailed on the tablet. This defixio ranks among the most interesting and original Latin curses and must have been written by someone learned, rhetorically competent, and wellversed in the literature of the day, probably a professional mage. ${ }^{30}$ The curse starts with a long list of supernatural entities whose main characteristic is the ability to exact revenge or snatch unsuspecting wrongdoers and carry them into the underworld. ${ }^{31}$

(41) Bevilacqua - Colacicchi 2009 (TheDeMa 517)

Virga, deum inferum [...] tu efficias illae Caeciliae Primae, quem admodum tu domas, caedis uris (per)uris ${ }^{32}$ ad Inferos eos, qui ad superos omnia mala sc(el)eraque fecerunt, sic tu Caeciliam Primam (ill)am, Virga, uras peruras caedas, domes do(n)ec, tamqu(a)m al oram egentes omnibus fortunis, mortua $(m)$ ad $t(e)$ abducas.

"Virga, of the infernal gods... may you cause that Caecilia Prima, just as you subjugate, hit, burn, annihilate to Hell those who have committed any kind of crime or impious act towards the gods, so may you, o Virga, burn, annihilate, hit, subjugate that Caecilia Prima, until you draw her dead to you, just as those who are devoid of any luck."

This simile formula mentions Virga (lit. a "magic wand"), here probably a personification of some higher divine power, a unique attestation in this sense, if correct. ${ }^{33}$ The term virga was often used as an equivalent of caduceus, the staff used by Hermes to call the ghosts of the dead to the underworld. ${ }^{34}$ In the Aeneid, Mercury uses a virga to summon souls from Orcus (tum uirgam capit: hac animas ille euocat Orco / pallentis, alias sub Tartara tristia mittit, / dat somnum adimitque, et lumina morte resignat) ${ }^{35}$ and similar magic wands are used by Athena and Circe as early as Homer; ${ }^{36}$ Ovid mentions Circe using a mirantia virga or "magic wand". ${ }^{37}$ In Latin, virga also denotes an instrument of

29 The myth of Hercules and Cacus is related by several Roman writers; cf. Verg. Aen. 8, 185-257; Liv. 1, 7, 3; Ov. Fast. 1, 543-86; Prop. 4, 9, 1-20. See Sutton 1977 on the reception of Greek material concerning Cacus in Latin literature.

30 Urbanová 2017, 72-74.

31 The supernatural entities invoked in this curse involve Dis Pater, Proserpina Dia, Canes Orcini, Ustores inferi, Ossufragae, Larvae, Furiae, Maniae, Aves Nocturnae, Aves Harpyiae, Ortygiae, Virga, Ximaera, Geryones, Siredonas, Circe, Gegantes, Spinx. On these beings, see esp. Bevilacqua 2010.

32 The reading is that of Bevilacqua - Colacicchi 2009, 307 and Bevilacqua 2009, 49; uris (per)uris does not match the facsimile, where the final $s$ is missing, i.e. (per)uri(s).

${ }^{33}$ Bevilacqua - Colacicchi 2009, 312-313.

34 As attested by Serv. In Aen. 4, 242: virgam id est caduceum, quod primo Apollo habuit et donavit Mercurio. For the term magica virga, see also Val. Flacc. 7, 212.

35 Verg. Aen. 4, 242-244.

36 Hom. Od. 10, 237-238, 293, 389.

37 Ov. Met. 14, 412. 
corporal punishment used by a lictor and a rod for controlling horses. The same tablet contains another longer simile:

(42) Bevilacqua - Colacicchi 2009 (TheDeMa 517)

...Geryones, Siredones, Circe, Solis filia, quemadmodum Minerva una tunica [...] abat eos monstrinae Siredenae cantibus homines detinebant Circe feralis medicamentis Ulixis socios[...] inem [...] atis Caeciliam Primam, isdem malis, isdem [d]oloris, Caeciliam adiuvatis, vitamque animam eius[...] eripiatis, inferis tradatis.

“...Geryon, Sirens, Circe, daughter of the Sun, just as Minerva [deceived?] them (i.e. the suitors) with only one cloth, the horrific Sirens caught men with their songs, menacing Circe [transformed?] Ulysses' fellows with her potions, [so] may you reward Caecilia Prima with the same sorrows and pains, may you snatch her life and her soul away and hand them over to the underworld."

The second simile seems to use Odysseus' travels as its source material. The text is damaged, but it seems that in most cases the similes refer to the magical transformations of persons by Athena and Circe. ${ }^{38}$ In another echo of Odysseus' homecoming, the "detention" of Caecilia Prima is to be effectuated by monstrinae Siredenae (Ovid's monstra maris $)^{39}$ and their enchanting songs. ${ }^{40}$ In both cases $(\mathbf{4 1}, \mathbf{4 2})$, the victim should be at the mercy of divinities and magical objects known from literary sources.

In what follows, we will introduce four tablets with identical provenance, dated to the 1st-2nd cent. CE. They have been found in Mogontiacum (modern Mainz) in a sanctuary dedicated to Mater Magna and Isis. ${ }^{41}$ These prayers for justice often incorporate a version of the lex talionis (a wish for a kind of a revenge that mirrors the harm suffered by the writer), which is typical for this subclass of defixiones. ${ }^{42}$ The similes are largely focused on the Galli, the priests of Magna Mater, and use imagery referencing the cult (e.g. the withering of a pine-tree, arbor siccabit se (45)); we find references to the act of self-castration

38 For a detailed discussion, see Bevilacqua - Colacicchi 2009, 324-325.

39 Ov. Ars am. 3, 311.

40 Hom. Od. 12, 39-40.

41 See Blänsdorf 2012; in connection with the cult of Mater Magna, see also Blänsdorf 2013, $122-123$.

42 Cf. Versnel 1991, Urbanová 2018, 180-197. There are also two extant Greek prayers for justice with an implicit simile formula aimed at retribution using the "eye for an eye" principle. These are not, however, defixiones sensu stricto, at least not in the material sense, since both prayers were written on marble steles as epitaphs; Salvo 2012, 238 refers to them as "epitaphs with a 'prayer for justice". Dated to the late $2^{\text {nd }}$ or early 1st cent. BCE and found at Rheneia (an island close to Delos), they betray a very strong influence from Hellenistic Judaism; cf. Van der Horst 1991, 148-149, and Van der Horst - Newman 2008, 137-143. Their texts are virtually identical, the only difference being the state of preservation and the name of the deceased (Heraklea and Marthina). In both cases, the writer, probably one of their relatives, wishes to "avenge the innocent blood" of the women. One of them may be cited here for reference (ID, No. $2532=$ TheDeMa 227):

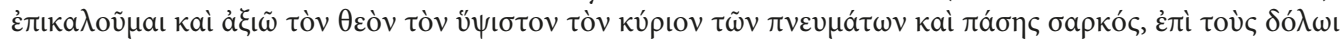

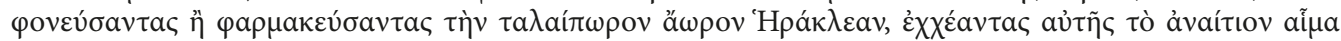

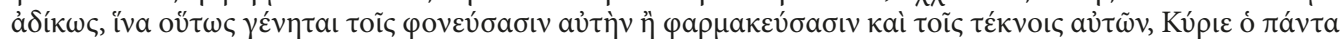

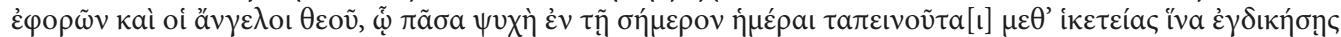

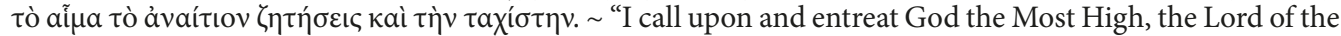
spirits and of all flesh, against those who have treacherously murdered or poisoned the wretched Heraclea, who died untimely, and who have unjustly shed her innocent blood, that the same may happen to them who have murdered or poisoned her and to their children, O Lord, you who see everything, and you, angels of God, for whom every soul humbles itself on the present day with supplication, that you may avenge and requite her innocent blood as soon as possible." (transl. Van der Horst — Newman). 
(praecidere (44), abscidere (45)), ${ }^{43}$ frenzied self-laceration (secare (43)), and spilled blood (sibi sanguin(em) ferventem fundunt (44)). ${ }^{44}$ The writers of the curses must have been familiar with these practices of the cult from processions of the Galli and the Bellonarii in the streets, even though the castrations themselves were not public events. ${ }^{45}$

\section{(43) DTM 1 (TheDeMa 758, LCT 231)}

Mater Magna, te rogo p(e)r (t)ua sacra et numen tuum: Gemella fiblas meas, qualis sustulit, sic et illam REQUIs (rogo?) adsecet, ${ }^{46}$ ut nusquam sana si(t). Quomodo galli se secarunt, sic ea(m?) velis nec se secet sic, uti planctum ha(be)at, quomodo et sacrorum deposierunt in sancto, sic et tuam vitam, valetudinem, Gemella. Neque hosti(i)s neque auro neque argento redimere possis a Matre deum, nisi ut exitum tuum populus spectet [...] rogo co(n)sument(u)r quomodo et res meas viresque fraudarunt, nec se possint redimere nec hosteis lanatis nec plumibis (=plumbis) nec auro nec argento redimere a numine tuo, nisi ut illas vorent canes, vermes adque alia portenta, exitum quarum populus spectet.

"Mater Magna, I ask you by your sanctuary and your divine force. Gemella who stole my bracelets [I ask you] may she cut herself ... so that no part of her be healthy. Just as the Galli have cut themselves, so [may] she want to do. And may she not cut herself so, that she may lament herself. As they have deposited the holy things in the sanctuary, so also your life and health, Gemella. Neither by offerings nor by gold nor by silver may you be able to redeem yourself from the Mater Deum [= Mother of the Gods], except that the people may watch your death. ... I ask they may be destroyed just as they have defrauded me of my property and resources; nor may they be able to buy themselves free either by offering sheep or by lead [tablets]; neither by gold nor silver may they buy themselves free from your divine power, until dogs devour them, worms and other horrible things; may the people watch their death. " (transl. Blänsdorf, modified)

The curse targets are Gemella and two other culprits named in parts of the curse we do not print. Verecunda and Paterna (targets of the formula following rogo co(n)sument(u) $r$ ) are to be afflicted by an irreversible curse that represents the lex talionis and a very strange and refined revenge. Not only does the text meticulously list all the misfortunes that are to befall the victims, ${ }^{47}$ but it also explicitly emphasizes the irreversibility of the curse, i.e. the fact that the targets will be unable to redeem themselves in any way. As for Gemella, the writer of the curse asks for a punishment analogous to the practice of the priests of Mater Magna, in whose sanctuary the tablet has been deposited, in the three following formulae: ...qualis sustulit... sic... adsecet; quomodo galli se secarunt, sic ea (m)

43 Alvar 2008, 420 states that "the contemporary inhabitants of the Empire were familiar with the Galli and Bellonarii of the cults of the Mater Magna and Ma-Bellona, who had castrated themselves in order to obtain personal sanctity by imitating Attis, but also with the accusations of sexual perversion levelled against them by their opponents." It is therefore quite possible that these rituals were associated with fear and disgust and may have been taken by the general populace to be a kind of a punishment. Dubosson-Sbriglione 2018, 139 argued that "les blessures que les galles s'infligeaient constituaient un parfait example des punitions que l'ont pouvait espérer pour son adversaire ou ennemi [i.e. for the author of the defixio]".

44 Alvar 2008, 172-173, n. 82. Gordon 2019, 128-129 speaks in this connection about "locally significant knowledge, where the rituals connected to the March festival provided valuable hints about how to formulate curses especially effective to the divinity addressed, namely Mater Magna and Attis". See also Gordon 2014, 780-783 for an excellent account of the magical practices of Mainz curses and prayers for justice, which interprets cult practice as a persuasive resource.

45 Alvar 2008, 250.

46 The term adsecet is problematic - we would expect se secet (i.e. "may she cut herself").

47 Such revenge is attested on another tablet from Germania (DFX 5.1.3/2, LCT 229, TheDeMa 259). 
velis... nec se secet uti planctum ha(be)at (with references to the frenzied self-laceration of the Galli); ${ }^{48}$ and, finally, quomodo et sacrorum deposierunt in sancto, sic et tuam vitam, valetudinem..., with references to the deposition of votive offerings dedicated to the goddess inside the sanctuary. This last formula mentioning the sacred space (in sancto) has further parallels to two tablets from Mainz $(43,45)$ and a recently published tablet from Kempraten (13). ${ }^{49}$

The following tablet has been written against an unknown scammer (quisquis dolum malum admisit de hac pecunia), and the writer is asking the Great Mother to hunt him. This prayer for justice, quite like the last one mentioned, uses the ritual practices and bloody self-laceration of the priests of Magna Mater and Bellona in three formulae (se secant et praecidunt vir(i)lia sua; sanguinem ferventem fundunt; spectat) as the basis for the persuasive analogy used as punishment and the lex talionis (neque auro neque argento neque ille solvi...), aimed at inducing the death of the offenders:

(44) DTM 2 (TheDeMa 763, LCT 232)

Quisquis dolum malum adm(isit de) hac pecun(i)a [...] Mater deum, tu persequeris per terras, per (maria, per locos) ar(i)dos et umidos, per benedictum tuum et o(mnes [...] qui de hac) pecunia dolum malum adhibet, ut tu perse(quaris illum [...] Quomodo) galli se secant et praecidunt vir(i)lia sua, sic il(le) [...] intercidat [...] pec(tus?) [...] neque auro neque argento neque ille solvi, (re)fici, redimi possit. Quomodo galli, bellonari, magal(i) sibi sanguin(em) ferventem fundunt, frigid(us) ad terram venit, sic et [...] copia, cogitatum, mentes. (Quem) admodum de eis gallo( $r) u(m, m a)$ galorum, bellon(ariorum) spectat, qui de ea pecunia dolum malum (admisit, sic illius) exitum spectent, et a (d qu)em modum sal in (aqua liques)cet, sic et illi membra $m(e d)$ ullae extabescant. ${ }^{50}$

"Whoever has defrauded this money... Mater Deum, you pursue [your enemies] across land [and sea], arid and humid [places], by your blessed one (= dead Attis), and everybody who commits malicious fraud concerning this money: you shall pursue him ... [Just as] the Galli lacerate themselves and sever their genitals, so may he cut... his chest [?] ... nor be he able to free or restore or redeem himself with gold nor with silver. Just as the adherents of Mater Magna and the priests of Bellona and the MAGALI spill their hot blood, which is cold (when) it touches the ground, so his ..., his abilities, his thinking and wits ... Just as ... of the Galli, the MAGALI and the priests of Bellona ... [Just as] he watches the person who commits fraud concerning this money, so let [the people] watch his death and ... Just as salt will [melt in water $]^{51}$, so may his limbs and marrow melt, may he be tortured and may he confess that he has committed sacrilege." (transl. Blänsdorf 2010)

The simile formulae referencing the castration and self-harm of the Galli seem to point to another annually celebrated ritual in the cult of the Great Mother, namely

${ }^{48}$ For the interpretation of this formula, see Blänsdorf 2012, 63: "Die beschuldigte soll sich zwar so wie die ekstatischen Kultanhänger schwer verletzen, aber anders als jenen soll ihr die Wehklage nicht erlaubt sein." LCT 231 reads "And may she not cut herself so, that she [only?] laments."

49 Editio princeps Frei-Stolba - Koch - Lieb 2015; for a new reading of the simile formula (qui dolum malum facit, sic iace[at] in xancto (=sancto) que[m]admodum haec epistula iacitura est), see Urbanová Franek - Barta 2019.

50 A similar idea might stand behind (16).

51 The term not attested elsewhere, but it is probably a variant of Galli, the name of the priests of Mater Magna. 
sanguem (on March 24). ${ }^{52}$ The sal et aqua illi fiat formula is known but always used in connection with the victim's property and business; ${ }^{53}$ in this tablet, it seems to be used in an unusual way: et a(d qu)em modum sal in (aqua liques)cet, sic et illi membra medullae extabescant. The idea of the melting or putrefaction of the victim's $\operatorname{limbs}^{54}$ also appears in the simile formulae in (9) (also from Mainz) and (46) below.

Another tablet from Mainz containing a prayer for justice mentions in addition to the self-mutilation of the Galli and Bellonari (absciderunt concideruntve se) also a special punishment for the culprit, namely his banishment from society, which seems to be based, once again, on a parallel with the Galli, the priests of Mater Magna living in seclusion (... nec illi in numero hominum sunt, neque ille sit). ${ }^{55}$ The second simile formula in the text of this tablet contains a wish for revenge in the spirit of the lex talionis: $Q(u)$ omodi et ille mihi fraudem fecit, sic illi, sancta Mater Magn(a), et relegis(ti) cu(n)cta. The last simile in this prayer for justice references yet again the specific features of the cult of the Mater Magna, namely the "withering of the 'tree' (i.e. the branch) in the sanctuary" (uti arbor siccabit se in sancto).

(45) DTM 6 (TheDeMa 765, LCT 234)

... Ita uti galli Bellonarive absciderunt concideruntve se, sic illi abscissa sit fides fama faculit(a)s. Nec illi in numero hominum sunt, neque ille sit. Q(u)omodi et ille mihi fraudem fecit sic illi, sancta Mater Magn(a), et relegis(ti? $)^{56}$ cuncta. Ita uti arbor siccabit se in sancto, sic et illi siccet fama fides fortuna faculitas.

"Just as the Galli or the priests of Bellona have castrated or cut themselves, so may his good name, reputation, ability to conduct his affairs be cut away. Just as they are not numbered among mankind, so may he too not (be so numbered). Just as he cheated me, so may you

52 As Dubosson-Sbriglione 2018, 97-100 showed, there are no reliable reports by classical authors concerning the exact nature of this ritual. It is probable, however, that the ritual was connected to arbor intrat mentioned below and that "les lácerations fasaient partie de la gestuelle qui accompagnait le convoi funébre. Ainsi il parait vraisemblable que la journée du sanguem était marquée par les lamentions et les auto-mutilations des membres de la communauté métroaque qui pleauraient la mort d'Attis". Gordon 2012, 204 noted that "[i]n Mainz there was evidently a contrapuntal relationship between public processions, particulary during the so-called March festival, where the galli and other servant of the goddess slashed themselves and bespattered the by-standers with their blood, and the writing of the tablets demanding punishment - the blood forming a metonymic link, among other things, to the spectacle of public execution". The term magalus is considered by Gordon 2012, 198 to be a "non-standard, even popular term, for a position that might have been more properly ${ }^{*}$ megarensis, corrupted under the influence of the words gallus and bellonarius; but it could equally be a vulgar form of Matris gallus or even Ma-gallus".

${ }^{53}$ Cf. DTM 4 (TheDeMa 757): Attis domine, te precor, ut hu(n)c (h)ostiam acceptum (h)abiatis, et quit aget, aginat sal et aqua illi fiat.

54 Terms denoting putrefaction or decomposition (tabesco, extabesco) are used quite frequently in defixiones, especially in those cases in which the petitioner wishes for the death of the victim; cf. TheDeMa $517,510,514,536,540,546,558,763$.

55 See Blänsdorf 2012, 100-103. Dubosson-Sbriglione 2018, 139 likewise argued that the Galli were considered to be socially excluded and conjured in the general populace "un image particulerement negative, peu enviable". See also Gordon 2012, note 38, who argued that "the fact that the galli are castrated, and so not 'man', grounds the claim that they are not human, which in turn provides a telling image for the fate of the target". The exclusion of a cursed individual from civilized society is very rare in defixiones. Usually, we find a wish to isolate the cursed individual from their loved ones (family, friends, partner), see, e.g., (40) (a prayer for justice) here and further love spells such as TheDeMa 807 (...agita a suis parentibus a suo cubile) and TheDeMa 821 (... ut obliviscatur patris et matris et [propinquor]um suorum et amicorum omnium [et aliorum] virorum amoris mei autem Fe[licis quem] peperit Fructa; Vettia que[m peperit Optata] ...).

56 We prefer Blänsdorf's reading relegis (2010) to his later one with relegisti (2012). 
(deal with him), holy Mater Magna, and take everything away from him. Just as the tree shall wither in the sanctuary, so may his reputation, good name, fortune, and ability to conduct his affairs wither." (transl. Blänsdorf)

As Jaime Alvar explained, "according to the myth, it was beneath a pine-tree that Attis emasculated himself and died [...], and this event was ritually reproduced at the festival of the Mater Magna on 22nd March, the day arbor intrat, when the dendrophori, whose duty it was, carried a pine-trunk into the temple, which then withered over the following weeks". ${ }^{57}$ As the last item in this section, the badly damaged simile in (46) below is again connected with the Galli and their self-inflicted suffering:

(46) DTM 12 (TheDeMa 754, LCT 237)

...quamodum gallorum angat se... s(ic i)lla aga(t), ut de se (pro)bant?, tu dom(i)na es, fac, ut $X$ mensibus... exitum illorum sit.

"...may she be anxious like the Galli are. ${ }^{58}$ May she go along, as she... [?] of herself. You are the Mistress; make them die within 10 months."

\section{V.Non-standard script orientation and aversus formulae}

Another widely attested comparatum in simile formulae is a non-standard orientation or arrangement of the curse text itself - this may play out in various guises, e.g. retrograde writing or upside-down orientation of the script, intentionally improper spelling. In Latin documents, references to "twisting" or "turning upside down" are extended beyond the script itself and create a special class we would term aversus formulae. Greek epigraphical evidence provides us with curses dated between the 5 th and 3rd cent. BCE (all from Attika), which make use of a distortion of the text to induce a similar "distortion" in the victim. In the oldest one, the words, deeds, hands, feet, knees, and soul of certain Kallias should become "twisted" or "distorted", just as his name on the tablet is. The spelling of the victim's name is intentionally "jumbled". ${ }^{9}$

(47) Münsterberg 1907, No. 2 (TheDeMa 416)

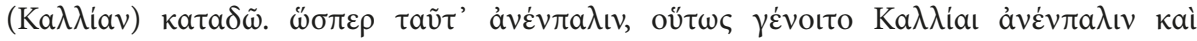

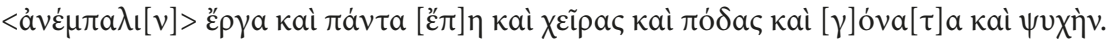

"I curse Kallias. Just as these [words] are [written] backwards, may everything become backwards for Kallias, [his] deeds and all [his] words, hands, feet, knees, and soul."

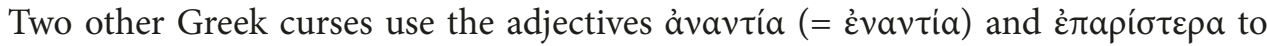
characterize their non-standard writing, the purpose being that the business of the op-

57 Alvar 2008, 70.

58 The verb ango may, in addition to mental distress, refer also to physical pain, which would be very much applicable in the case of the Galli.

59 SGD, No. 40. A facsimile is printed by Münsterberg 1901, 595 in his editio princeps; see also Münsterberg 1907,376 . The text is written in three rows; we are reproducing only the middle row since the formula is similar in all three instances, albeit with three different cursed targets. The first row reads ... $\omega \sigma \pi \varepsilon \rho$

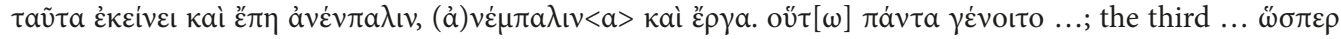

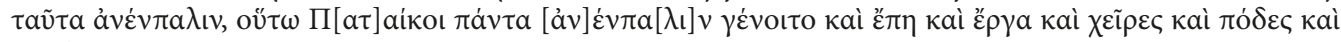
$\psi v x \dot{\eta}$. 
ponents should likewise become "reversed" and "left-handed". In the former, republished recently by Jaime Curbera and dated to the 4 th cent. BCE, the writer of the curse targets his or her marketplace competition (quite like the curse against Babylas, item (39) in our corpus):

(48) Curbera 2015, No. 1 (TheDeMa 673)

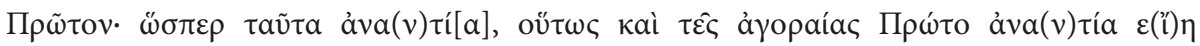

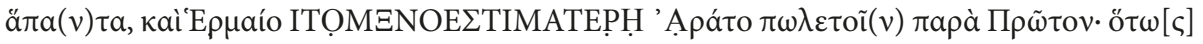



"Proton - just as these (letters) are jumbled up, so too of Proton the market-woman be jumbled up all things, and also (those) of Hermaios, the son of Timoxenos, of Timarete, the daughter of Aratos, the two sellers near Proton. And so also Aetos (the) seller. Bind these down and their business." (transl. Curbera)

The twisting of the names in lines 5 and 6 "is explained in terms of sympathetic magic", ${ }^{60}$ yet it is surprising that the name "Proton" is written in a regular manner. The last example of the magical manipulation of the script with an accompanying performative simile is provided by a legal curse from Athens, dated to the 3rd cent. BCE and containing simile formula (18). Following a list of names written in a retrograde manner, the curse on the recto side continues as follows:

(49) Curbera - Papakonstantinou 2018, No. 3 (TheDeMa 955)

...

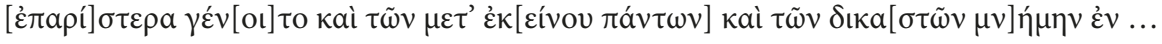

"Just as these words are cold and written backwards, in the same way may the words of Kratês be cold and backwards and all standing on his side and the memory of the judges ..." (transl. Eidinow, modified to reflect the new reading by Curbera and Papakonstantinou)

In addition to the retrograde writing, the comparatum of the simile formula also mentions the "coldness" of the "words" ( $\dot{\rho} \eta \dot{\mu} \mu \tau \alpha)$ - a trademark attribute of these curses, used also in relation to the lead tablet itself (see similes (1) and (3) in our corpus) and Section VI below. In Latin curses, a simile formula that serves the purpose of "inverting", "perverting", or "turning upside down" uses prefixed derivatives of the Latin verb vertere, usually in the form of one of the participles aversus, perversus, inversus, or interversus. The formula makes use, by means of persuasive analogy, of both the primary meaning of the prefixed derivatives of vertere (i.e. "to turn", "to inverse", "to distort") and the metaphorical one (i.e. "to be unfavourable", "to be hostile", "to be averse to", "to be depraved"). The formula is very often accompanied by a magical orientation of the script - the entire text or a part of it is written upside down or from right to left, that is, "adversely" or in a "perverted" way, in order to "turn" the target upside down and harm it.

One of the three instances in Latin curse tablets in which a non-standard orientation of the script is absent is the tablet containing simile (35), cited here in Section III, see also tablets (55) and (56) in Section V. This is due to the fact that the "turning upside down" was realized during the ritual by manipulating the unfortunate puppy. The text of the

60 Curbera 2015, 144. 
simile would seem to indicate that the puppy was also pierced through (sic transfixi sint quomodo ille catellus) with a further undetermined sharp object, probably a nail (as defixiones quite often are, hence the name) or a dagger. As for the gruesome details of what exactly must have happened to the puppy in order for it to qualify as catullus aversus, we leave that to the reader's imagination.

(50) DT 111-112 (TheDeMa 190, DFX 4.3.1/1-2, LCT 67-68)

...aversos (=aversi) ab hac l(i)te esse (debent?). Quomodi hic catellus aversus est nec surgere potest, sic nec illi, sic traspecti (=transfixi) sin(t) quomodi ille.

"... [and] so [may] also these [legal] opponents be turned back from this suit, just as this puppy [lies] upside down and is unable to stand up, so [may] they [be unable to stand up]; may they be pierced through, just as this [puppy is]".

Aversus formulae occur six more times in the Latin documentation, and these remaining cases are always connected with an unusual way of writing, applied to either the entire text of the tablet or the names of the victims, as is the case with the tablets from Raetia and Germania, which are dated to the 1st to 3rd cent. CE (they are usually written right to left or the letters are written upside down). A curse from Cologne, dated to the 1st cent. CE and written in its entirety from right to left, uses a persuasive analogy based on a non-standard orientation of the script in the following way:

(51) Blänsdorf - Kropp — Scholz 2010 (TheDeMa 258, LCT 100)

A: Vaeraca, sic res tua: perve(r)se agas, quomodo hoc perverse scriptu(m) est. B: Quidquid exopt(a)s nobi(s) in caput tuum eveniat.

"A: Vaeraca, this is how it is going to be for you: may you go along twistedly [i.e. wrongly] just as this is written in a twisted way [the text is written right to left]. B: Whatever [evil things] you wish for us, may they come down upon your head."

The magical analogy in the simile quomodo hoc perverse scriptu $(m)$ est - perverse agas makes use of the irregular way of writing as a magical device to destroy Vaeraca, or as a preventive counter-spell. ${ }^{61}$ It is obvious that the phrase perverse agas here means something like "may you fare badly", "may everything turn against you". The following tablet from Rottweil, dated to the 1st-3rd cent. CE, features a prayer for justice that is written not only right to left, but also partially upside down. The particle quomodo is missing, but it is safe to assume that the expression sicut hoc est aversum acknowledges the fact that the whole text of the tablet is written in a non-standard way. ${ }^{62}$

(52) TheDeMa 767 (DFX 5.1.7/1, LCT 230)

Fib(u)lam Gnatae qui involavit aut qui melior est animi conscius, ut illum aut illam aversum faciant dii sicut hoc est aversum et qui res illaeus sustulit.

${ }^{61}$ For this reading and interpretation, see Blänsdorf - Kropp — Scholz 2010, 272-274; see also Faraone - Kropp 2010, 395-398. See also LCT 100 - a possible counter-spell.

62 See Faraone - Kropp 2010, 387-393 and LCT 230 for further commentary and discussion. 
"Whoever carried off Gnata's fibula or knows something more about it, may the gods turn [his or her life or business] upside down, just as this [text] is turned upside down; [this holds for] the one who stole her property."

A recently published curse text from Gellep (Germania), dated to the 1st cent. CE, has a unique layout. ${ }^{63}$ In addition to various orientations of the script, the writer was trying to "isolate" the proper names of the victims or endow them with a special significance and focus. ${ }^{64}$ The author seemingly first wrote the list of the names of cursed individuals, all in the nominative, with each name given a separate line and all of them written from right to left. The curse proper was inscribed only after the preparation of this list. The curse formula is below the names, and a slightly modified version of it even frames the victims' names on the right side, written vertically from top to bottom. Every detail seems to be well thought out, and the use of the simile formula with perversum undoubtedly references the list of the names that are written from right to left.

(53) Blänsdorf 2014 (TheDeMa 1621)

Como hoc perversum scriptum est, sic illos dei spernent. [written vertically on the right side of the tablet] Theudocsius Lupicinus Iustinianus Leontius Terentianus Aelario Hermoginis Mastidius / Mustidius [written from right to left] Conmo (=como) (h)oc perversum est, sic no(n) pos[...] o addi nilum cui possit.

"Just as this is written in a perverted way, so may they be condemned by the gods. [the text continues with an enumeration of the names of the victims] Just as this is [written] in a perverted way, so may they not... and [so that] nothing may be added to it." (transl. Blänsdorf)

Another strategy in the use of "perversion" of script as the basis for a persuasive analogy in sympathetic magic relates to the name of the target - in the following two tablets, only the name of the victim was written in a non-standard way. In a curse from Mautern, interpreted as a love spell, ${ }^{65}$ the simile formula has the following form:

(54) DFX 6.1/1 (TheDeMa 768, LCT 101)

A: Pluton sive $\{m\}$ Iovem infernum dici opor\{no\}tet (A)eracura Iuno inferna, acciet $(e)$ ia $(m)$ $c(e)$ lerius infrascribtum e $(t)$ tradite $\{i\}$ Manibus Aurelium Sinnianum $C\left(\right.$ a)eserianum ${ }^{66}$ B: Sic Silvia inversu $(m)$ maritu $(m)$ ce\{e\}rnis, quommodi nomen il(l)ius scriptum est.

"A: Pluto, or, if it is fitting to say the infernal Jupiter, Aeracura, the infernal Iuno, summon the one written below as fast as possible and hand over Aurelius Sinnianus Caesarianus to Manes. B: May you, Silvia, see your husband upside down, just as his name is written."

63 Cf. Blänsdorf 2014, 181-186 for a new reading; the editio princeps was published by Galsterer 2000.

${ }^{64}$ Proper names have a special status in magical and religious thinking since every name is regarded as an inextricable part of the person or thing it denotes. Thus, according to the principle of magical analogy, the life of any individual can be affected by the ritual use of the name he or she bears; see Petersmann 2002, 29; Jevons 1908, 107; Urbanová 2019, No. 20.

${ }^{65}$ Egger 1963, 24-33 considered Silvia to be the name of the author, which is, however, not common in curses; therefore, he interpreted the text to be a love spell, as the author's name is usually stated in these; for a new, in our opinion correct, interpretation, see Faraone - Kropp 2010, 387-393; Weber 1985, 62-65 viewed the tablet as a love spell.

66 The victim's name (Aurelius Sinnianus Caesarianus) is inscribed from right to left and upside down. Inversum means "the other way round, upside down" and refers to not only the way the victims name is inscribed, but also the persuasive analogy anticipating that the victim will also be "inverted" in a way. The committal of the victim to underworld ghosts (Dis Manibus) and Pluto probably means death. 
An analogous use of aversus along with the writing of the victim's name upside down, albeit without the explicit use of a simile formula, is attested also on a tablet from Mainz (45): Quintum in hac tabula depon(o) aversum, ${ }^{67}$ with the tablet also containing the sequence QUINTI NOMEN written upside down. ${ }^{68}$

In the following three Latin curses with aversus, the basis for the persuasive analogy is not non-standard writing per se (the text is written in a completely regular fashion, left to right with the proper orientation of the letters). In order for the sympathetic magic to work, something had to be twisted, turned upside down, or perverted - as was the case also with (50), where the twisting and turning was effected on a puppy. In the following three examples, it is probable that the basis has been supplied by a graphium aversum, the "twisted" or "distorted" stylus used to write the curse. The term graphium has been known from Mainz for quite some time - our items (56) and (57) -, but the correct interpretation has been made possible only after the discovery and publication of a new Aquincum tablet and concomitant archaeological findings by Andrea Barta in 2009 and 2019. ${ }^{69}$ The Aquincum curse has been dated to the 2 nd-3rd cent. CE and has a legal context, and the simile runs as follows:

(55) Barta-Lassányi 2015 (Barta 2009, No. 1, TheDeMa 1106)

...Et Decibali lingua et nomen ne possit adversus Oceanum facere. Eo modo hoc ego averso graphio scribo, sic linguas (=linguae) illorum aversas (=aversae) ne pos(s)int facere contra (h)os...

"And may the tongue and [Decebalus as a person] be unable to act against Oceanus. Just as I write this with a perverted stylus, may their tongues be perverted so that they cannot act against these ..." (transl. Barta)

As has already been pointed out, the text on this curse does not feature any unusual orientation of the script. Interpretation posed significant challenges, but a breakthrough was achieved when Barta made a connection between the curse tablet and a stylus that was originally found next to it (originally categorized, but deemed unconnected to the tablet). The stylus was examined by the Restoration Department of the Budapest History Museum and examination proved that it must have been bent before it sank into the ground and that the bending was intended by its original user ${ }^{70}$ Both the sources and the physical examination make it plausible that the bent stylus found next to the curse tablet is the graphium aversum mentioned in the curse text. The conclusion, if accepted, sheds new light also on the following two texts from Mainz (in both, as in the Acquincum curse, the orientation of the script is normal).

The first tablet from Mainz is a prayer for justice, aimed at a thief who stole some money and golden rings, dated to the 1 st- 2 nd cent. CE:

67 TheDeMa 765 (LCT 234).

68 See DTM 6 and Faraone - Kropp 2010, 386.

69 See also Urbanová - Franek 2019, No. 18, 19.

${ }^{70}$ For further details, see Barta (2019, in print). 
...quo) mod(i) hoc grapphio averso, quod minime uti solet, sic (eum) aversum dii deae\{e\}que [...] (e) sse $\sin \{e\} a t(i)$ s...

“... just as this [is written] with a twisted stylus, ${ }^{71}$ which is not usual at all, so may you, gods and goddesses, make $[$ him] perverted...”

It seems likely that a graphium aversum has been used in this case as well, and its uniqueness and essential nature for the persuasive analogy to work (since the script is not distorted in any way) is highlighted by the injunction quod minime uti solet. The last curse that could be added to this category is another prayer for justice from Mainz, also dated to the 1 st-2nd cent. CE. ${ }^{72}$ It does not contain an explicit reference to a graphium, but since it does not feature a non-standard orientation of the script, we believe that the term averse scribo could be taken as equivalent to averso graphio scribo.

(57) DTM 3 (TheDeMa 289, LCT 233)

Rogo te, domina Mater Magna, ut me vindices de bonis Flori coniugis mei, qui me fraudavit Ulattius Severus, quemadmod(um) hoc ego averse scribo, sic illi omnia, quidquid agit, quidquid aginat, omnia illi aversa fiant, ut sal et aqua illi eveniat.

"I entreat you, Lady Mater Magna, to avenge me regarding the property of Florus, my husband, [of which] Ulattius Severus has defrauded me. Just as I write this in a twisted way, so may whatever he does and carries out be twisted (i.e. frustrated), may it become salt and water [= salty water]."

The text seems to say that the widow of Florus was deprived of some of her property by Ulattius Severus - Blänsdorf assumed that this man may have been the administrator of the widow's estate. ${ }^{73}$ Since women had no right to take legal action, she resorted to magical means and implored the deity for justice to be done. ${ }^{74}$

\section{Name (ővoua)}

No less than 14 Greek curse tablets contain a simile formula including "names", óvó $\mu \tau \tau \alpha$, as comparatum. They exhibit almost identical formulae, all of them have been found in a well near Athenian Agora, and all of them are dated to the 3rd cent. CE. Most of them seem to originate from the same magical workshop and some are written by the same hand. ${ }^{75}$ Some of them are agonistic curses, others amatory, and others still are

${ }^{71}$ Cf. the translation by Blänsdorf, DTM 7: “with a reversed (hostile) stylus". Blänsdorf, interpreted the puzzling expression grapphio averso figuratively as "with a reversed, hostile, adversarial stylus". Christopher Faraone and Amina Kropp 2010, 390-392 recently offered another solution; they interpreted the word graphium as a Greek loan word and a lexical innovation: "It is quite likely that graphio was a verb belonging to the spoken variety of Latin, which eventually developed into the modern Italian graffiare 'scratch."'

${ }_{72}$ For a reading and interpretation, see also Blänsdorf 2010, 172; see also Faraone - Kropp 2010, 390-393.

73 Blänsdorf 2010, 153.

74 Cf. also DTM 1 (TheDeMa 758, LCT 231): TAMAQVANIVSCAVERSSO scriptis istas - we might infer a simile forumla in the damaged part of this tablet.

75 These include the following: SEG 35:213 (= SGD, No. 24 = Jordan 1985a, No. $1=$ TheDeMa 1); SEG 35:214 (= SGD, No. 25 = Jordan 1985a, No.2 = TheDeMa 2); SEG 35:215 (= SGD, No. 26 = Jordan 1985a, No. 3 = TheDeMa 3); SEG 35:216 (= SGD, No. 27 = Jordan 1985a, No. 4 = TheDeMa 4); SEG 35:217 (= SGD, No. 28 = Jordan 1985a, No. 5 = TheDeMa 5); SEG 35:218 (= SGD, No. $29=$ Jordan 1985a, No. 6 = TheDeMa 
quite hard to classify, but the simile formula invariably alludes to "names" (óvó $\mu a \tau a)$ that

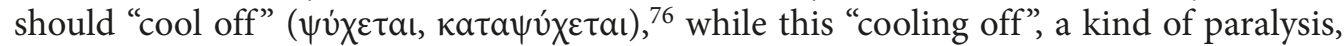
should afflict the targets of the curse, especially their body parts, but also some more abstract qualities and attributes. We cite here only two representative examples, one simpler and the other more elaborate:

(58) Jordan 1975 (TheDeMa 404)

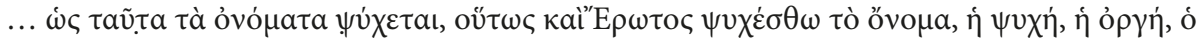

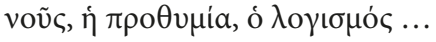

"As these names are chilled, so too let the name, the soul, the passion, the mind, the spirit, the reasoning of Eros be chilled." (transl. Jordan)

(59) SEG 35:227 (TheDeMa 412)

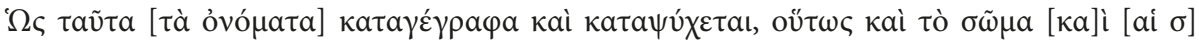

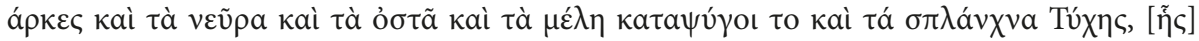

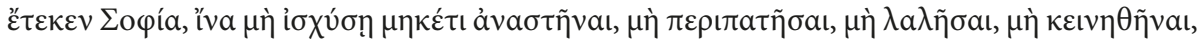

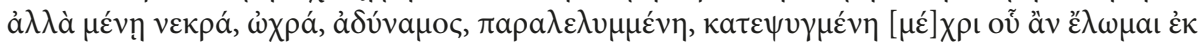

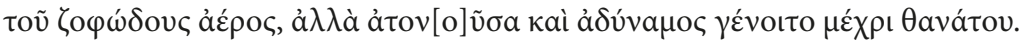

"As I have written down these names and they grow cold, so, too, let the body and the flesh and the muscles and the bones and the members and the bowels of Tyche, whom Sophia bore, grow cold, that she may no longer rise up, walk around, talk, move about, but let her remain a corpse, pale, weak, paralyzed, chilled until I am taken out of the dark air, rather let her grow exhausted and weak until she dies." (transl. Jordan)

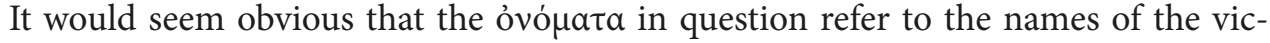
tims. ${ }^{77}$ The case is not that clear, however, since on several occasions there is clearly only one person being targeted while "óvó $\mu \alpha \tau \alpha$ " remains in the plural. ${ }^{78}$ In our view,

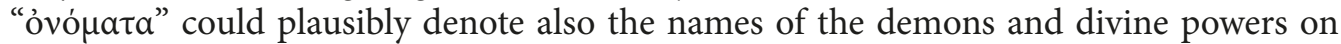
these tablets. The tablets in question contain many voces magicae - they quite often start with a BORPHOR-sequence and mention, amongst a host of others, the likes of SETH, TYPHON, BETPY(T), SABAOTH/SACHAOTH, I(A)O. If the Greek magical papyri are of any guidance, "óvó $\mu \alpha \tau \alpha$ " refers exclusively to the names of demons and one of the spells even seems to detail the modus operandi of using the names of demons in the context of homeopathic magic. In an instruction to prepare a small lead tablet, the practitioner was supposed to write on it a series of voces magicae (including IAO and SABAOTH) and then put it into his or her shoe. The resulting action of quite literal "trampling" the óvó $\mu a \tau a$

6); SEG 35:220 (= SGD, No. 31 = Jordan 1985a, No. 8 = TheDeMa 103); SEG 35:219 (= SGD, No. 30 = Jordan 1985a, No. 7 = TheDeMa 405); SEG 35:221 (= SGD, No. $32=$ Jordan 1985a, No. $9=$ TheDeMa 406); SEG 35:222 (=SGD, No. 33 = Jordan 1985a, No. 10 = TheDeMa 407); SEG 35:223 (= SGD, No. 34 = Jordan 1985a, No. 11 = TheDeMa 408); SEG 35:227 (= SGD, No. 34 = Jordan 1985a: 251-255 = TheDeMa 412); Elderkin 1937 (= SGD, No. 22 = TheDeMa 403); Elderkin 1936 (= SGD, No. 23 = Jordan 1975 = TheDeMa 404).

76 As Gager 1992, 51 noted, there is clear connection between the location (a well) and the process of "cooling off" or "growing cold" - in ancient Athens, the insides of a deep well would be one of the more reliably cold places one could find.

77 Elderkin 1937, 389; Jordan 1985a, 247 clearly holds this view, although he recognizes the difficulty that sometimes "plural names are to be chilled with regard to one person".

78 See, e.g., the first three items in our note 75. All three curses target Eutychianos, yet in all three the "names" in the simile formula are in the plural form. 
that had been inscribed on the tablet, as well as the name of the victim, was believed to be magically transferred to the target of the curse, referenced here, as is usual in the PGM,

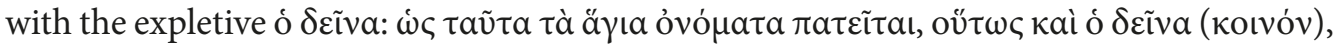
o $\dot{\varepsilon} \pi \dot{\varepsilon} \chi \omega \nu$ ("Just as these sacred names are being trampled, so also let him, NN (add the usual), the troublemaker, be trampled"). ${ }^{79}$

In the case of Latin curse tablets, we find the term nomen frequently used, but (contrary to the Greek óvó $\mu \alpha \tau \alpha$ ) it refers to voces magicae or the secret and powerful names of divinities and demons only when it is supplemented by another qualificative, e.g. sancta nomina or nomina necessitatis. ${ }^{80}$ In a simile formula, we find the term nomen twice; both cases have already been discussed, in (54) and (55).

\section{Drawings}

In our last category, we include two Greek curses and one Latin curse in which the persuasive analogy is effectuated via drawings (or, rather, etchings). ${ }^{81}$ In all three examples, victims are depicted on the tablet visually and the simile formula refers to the drawings with the intention of transferring onto the enemy the tortures they are subjected to in the drawings. A peculiar curse containing a longer series of simile formulae has been found at Kos and is dated to the 4 th cent. CE. The curse text proper is written on the recto side (with three lines also on the verso side); on the verso side, there is a large drawing of a daemonic creature, identified with Typhon-Seth, ${ }^{82}$ holding the victim (a certain Hermias, son of Pythias) by the hair.

(60) SEG 47:1291 (TheDeMa 189, see Fig. 1) $)^{83}$

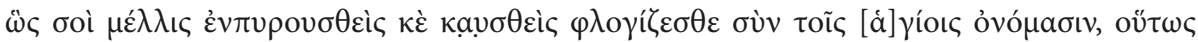

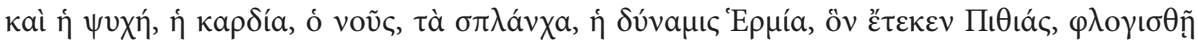

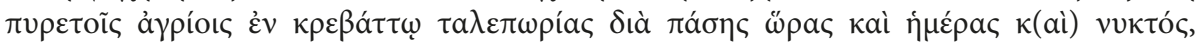



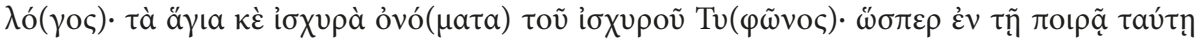



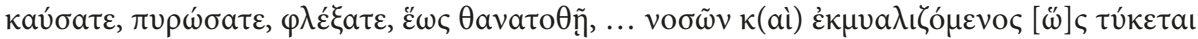

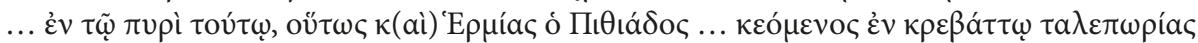
$\dot{\varepsilon} \kappa \mu v a \lambda ı \sigma \theta \tilde{n} \kappa(\alpha i) \theta a v a \tau \omega \theta \tilde{\eta}$.

"Just as you, after being lit up and set on fire, will burn with the holy names, so let also burn the soul, heart, mind, guts, and power of Hermias, whom Pithias bore, in wild fever, on a bed of torture, every hour of the night and day, melting down, wasting away, being sucked

79 PGM X, 36-50. The entire spell is introduced in the following way: "Take a lamella [or metal leaf] from a yoke for mules and engrave on it the following names and put a frog's tongue in it. Spell, when the metal leaf with the frog's tongue is put into your sandal, [say:]" English translations by Betz 1986, 150.

${ }^{80}$ See Urbanová - Franek 2017 for a detailed analysis.

81 On drawings, see West 2011; Martín Hernández 2012; Sánchez Natalías 2013; on figurines, see Bailliot 2015.

82 See further BE 1998, No. 73 and EBGR 1997, No. 195. The Greek Typhon has been identified with the Egyptian Seth as early as Herodotus $(2,144 ; 2,156 ; 3,5)$. There are multiple references to Typhon-Seth in the Greek magical papyri (including visual representations); see, e.g., PGM XIVc, 15-27; PDM XIV, 675694; and Lucarelli 2017; Pachoumi 2017, 143-149; and Dieleman 2005, 130-138 for an overview.

${ }^{83}$ For the Greek text, we use the latest editio published in 2018, that of IG XII 4, 4, 3401. For editio princeps and the drawing, see Kantzia (1997). 
dry, until he dies. [...] O [mighty] word, ABERAMENTHO, [mighty] word ACHAR, holy and strong names of strong Typhon! Just as you are to be burned in this fire with the holy demon Typhon, burn also the horrible and lawless Hermias, son of Pithias, set him on fire and engulf him in flames until he dies ... feeble and sucked dry, as he is melting away ... in this fire, so let Hermias, son of Pithias ... burning on a bed of torture, let him be sucked dry and die."

The underlying idea that the physical manipulation of a tablet (throwing it into the fire or otherwise burning it) should produce the same effects in the victim has been already observed in Latin curses (9). In this case, however, the tablet makes it explicit that


primarily being subjected to the flame, and not the curse tablet as such. Another Greek example belongs to one of the most famous series of ancient Greek defixiones, the socalled "Sethian" curses from Rome. Dated to the 4 th-5th cent. CE, they contain one interpretable tablet with a simile formula: ${ }^{84}$

(61) DT 155 (TheDeMa 178; see Fig. 2)

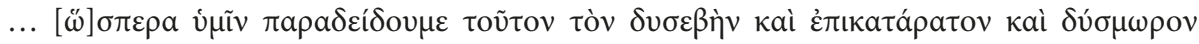



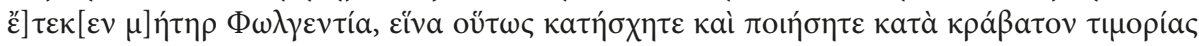

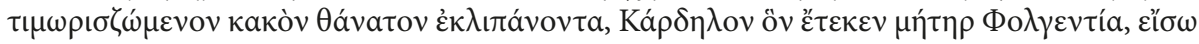
$\grave{\eta} \mu \varepsilon \rho \tilde{\omega} \nu \pi \dot{\varepsilon} v \tau \varepsilon \ldots$

“...just as I hand over to you this impious, accursed, and miserable Kardelos, to whom his mother Pholgentia gave birth, bound, fully bound, and altogether bound, in order that you may in the same way restrain him-Kardelos to whom his mother Pholgentia gave birthand make him bedridden and (make him) suffer the penalty of an evil death and expire within five days-Kardelos to whom his mother Pholgentia gave birth..." (transl. Gager)

Just like (60), this defixio, commonly considered an agonistic curse, ${ }^{85}$ is accompanied by a drawing (multiple ones, in fact) - a common feature of the "Sethian" curses, some of which contain depictions of a demon-like-creature whose identity has generated vivid discussions, which we will delve into here. In addition to this demon, our tablet also contains a depiction of a human body resembling a mummy around which two snakes are coiled. Since the comparatum of the simile is Kardelos, who is "bound, fully bound, and altogether bound", it is most likely that the mummy-like contours represent bound Kardelos. ${ }^{86}$ The depiction of the enemy in such a sorry state should then produce, by persuasive

84 There is a second simile clearly present in DT 162 (Wünsch 1898, No. 23, TheDeMa 73), .. $\ddot{\sigma} \pi \varepsilon \rho$



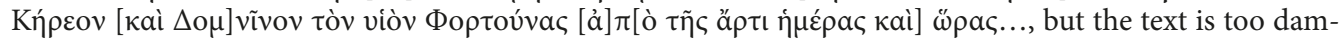
aged to make sense of it.

85 See, e.g., Gager 1992, 68, or Wilburn 2012, 2. Heintz 1998, 198 argued that the formulaic and visual similarities between this tablet and the others in the "Sethian" series (undoubtedly agonistic) do not necessarily mean that this defixio is agonistic as well.

86 Viglione 2010, 121: "Ai piedi del demone compare la figura di una mummia avvolta dalle spire di due serpenti, disposta perpendicolarmente rispetto a tutte le altre immagini del documento, verosimilmente la vittima dell'azione magica, che, come si apprende dal testo, è un tale di nome Káp $\delta \eta \lambda$ oc figlio di $\Phi \omega \lambda \gamma \varepsilon v \tau i ́ a$, del quale viene richiesta una brutta morte fra atroci tormenti .... Cf. also Wilburn 2012, 5, who described it as "image of a mummified individual around which wrap two snakes, shown bearded with forked tongues. The mummy is decorated in the same fashion as the figure in the upper left-hand corner, 
analogy, his paralysis also in the real world, on the basis of the same sympathetic magical thinking that is also operating in the case of voodoo dolls and kolossoi sometimes found alongside curse tablets - indeed, a defixio accompanied by a wax figurine of the victim "in the very act of being gulped down by a snake which is coiling itself around his body" has been found at the spring of Anna Perenna, also in Rome. ${ }^{87}$

The only extant Latin curse that would make use of a drawing in combination with a simile formula referencing that drawing is an agonistic defixio dated to the 3rd cent. $\mathrm{CE}$ from Carthage. The drawing is an extremely basic rendering of a human figure with crossed hands and feet that are bound (represented on the drawing by circles where the figure's hands and feet are crossed). ${ }^{88}$

(62) Jordan 1988, No. 3 (TheDeMa 68, DFX 11.1.1/37, LCT 140, see Fig. 3)

$\sum \varepsilon \mu \varepsilon \sigma \varepsilon ı \lambda a \mu,(q)$ uomodo tomacos (h)abes ligatos, sic et Concordi [...] liget brac(ch)ia, cor, sensu(m) [...] Q(uomod)o ped(es) (h)abes l(igat)os, sic et eius Salbi (eis albis?) ligatae (=ligate) pedes Alumn $\{i\} o$ et Pyr(rh)o, Polyarci et Lascovuo (=Lascivio?) obligat $\{a\}$ e pedes [...] ut obruant.

"SEMESEILAM, just as you have your entrails tied up, ${ }^{89}$ may he bind the arms, heart, sense of Concordius ... just as your feet are tied up, may you [plural] bind the hooves of [the horses of the white team? $]^{90}$ Alumnus and Pyrrhus, bind up the hooves of Poliarcus and Lascivius... so that they fall over." ${ }^{\prime 1}$

\section{Conclusions}

Despite the inherent randomness of our epigraphical documentation, the data available to us show clearly that since the 5th cent. BCE, the nations inhabiting the Mediterranean area practised a sort of a magical koiné - a shared repertory of magical prescriptions, rituals, and formulae. These are attested not only in Greek and Latin, but also in Hebrew, Oscan, Etruscan, Demotic, and even Celtic, spanning the area of the entire Roman Empire at the time of its greatest geographical extent, from Syria and Northern Africa to Britannia and the shores of the Black Sea. For the purposes of this study, we have collected and discussed here 85 formulae ( 34 Greek and 51 Latin ones) attested on 57 tablets (27 Greek and 30 Latin ones; on occasion, one tablet contains more than one simile formula).${ }^{92}$ Most of

with a crosshatched pattern. This is likely the putative target of the spell, dead and buried." Compare also with Wünsch 1898, 19-20, No. 17, featuring a similar drawing of a mummified man around whom a snake is coiled, and White 1999, 85-86. For the Graeco-Egyptian influences on the drawings, see esp. Gordon 2018, 108-112, who discusses also this tablet.

87 Sánchez Natalías 2015, 200; cf. also Piranomonte 2012.

88 See Jordan 1988, 129-130 for the drawing and visual parallels in the "Sethian" curses.

89 Another parallel from Latin curse texts is the curse against Porcellus Mulomedicus (TheDeMa 257). The text of the curse is written under a drawing of a deity with hands crossed on its belly; the text then continues alongside the second drawing of the victim, lying and tied up, as if mummified, with his hands crossed over his belly, analogically to the drawing of the deity depicted above, and the name Porcellus inscribed on his arms; see Sánchez Natalías 2011, 209.

${ }^{90}$ Jordan 1988, 133 takes into consideration also the possible readings eius Albi and Salvi; see also Tremel 2004, 68 and LCT 140.

91 This is a rare example of a simile formula used in combination with a formula using the imperative.

92 In total, there are around 80 Greek and Latin tablets containing a simile formula. The number is smaller here since, in the case of "serial" curses, we have cited in full only a few representative examples. 
the Greek tablets are dated to the centuries before the Common Era (16, of which 11 were written as early as the 5th-3rd cent. BCE), while the clear majority of Latin tablets (26) are from the first three centuries of the Common Era.

With respect to genre, curses in legal contexts are the most numerous (11 Greek and 8 Latin curses). Eight Greek tablets are non-specific, followed by agonistic (three) and separation (three) curses, with only a single love spell attested (38). In Latin documents, the most numerous examples are prayers for justice (12), followed by curses in a legal context (8), separation curses (5), and non-specific curses (3). With respect to the place where the tablets were deposited, the majority were placed into a grave (31) and some deposited in a sanctuary (11) or a well or other water container (5). In 10 instances, we are unable to pinpoint the exact location of the archaeological find, but often it is possible to deduce it from the contents of the curse itself. In general, it may be concluded that in the simile formula the basis for the persuasive analogy was in most cases either some "natural" property of selected items (the "ineffectiveness" of a dead body, "coldness" of lead, "muteness" of Manes, etc.) or the active manipulation of these items (an animal that is killed or mutilated during the accompanying ritual, a tablet that is thrown into a fire, a stylus that is bent on purpose, etc.).

The most compact category in the Greek and Latin similes is the dead human body or its ghost (our Section II), attested on 10 Greek and 6 Latin tablets. Notwithstanding the chronological and geographical divergences, the similarities in the use of the formulae are striking: The comparata in the simile formulae are often human corpses of "special" dead $(\mathbf{1 7}, \mathbf{1 8}, \mathbf{1 9} ; \mathbf{2 0}, \mathbf{2 1})$ and these are sometimes invoked by their personal names - Pasianax $(\mathbf{2 2}, \mathbf{2 3})$, Theonnastos (24), Oltis (26), Securus (25). Most of these curses were written in the context of a legal battle or business $(\mathbf{1 8}, \mathbf{2 2}, \mathbf{2 3}, \mathbf{2 6}, \mathbf{2 5})$ or a rivalry in love $(\mathbf{1 7}, \mathbf{2 4}$, 20,21 ). In both of these cases, specific properties of the dead bodies are to be transferred to the victims - the cursed individuals should be unable to testify or speak against the cursing party, or even make it to the court (25); the victim should become "ineffective"


in (22) and (23). In the case of Latin, separation spells $(\mathbf{2 0}, 21)$ work in a similar manner - the victim should be as hated as the corpse with which the tablet has been deposited (ut ille illam odiat) in (20); the victim should become mute, disliked by both gods and humans and his or her worth should be as (low as) the corpse's in (21). Other tablets from this section turn to the ghosts of the dead (nekydaimones), again mostly in legal contexts $(27,28,29,30,31,32)$. The ghosts of the untimely dead are "wordless and speechless" (ä $\alpha \alpha \lambda$ o $\kappa \dot{\varepsilon} \alpha \ddot{\gamma} \gamma \lambda \omega \sigma \sigma o l)$ in (28) and so should become the enemies of the writer; in (29), the writer even asks for the victims to be carried down into the underworld. Similar magical operations are established in (30) and most likely also (32). In (31), the writer addresses himself or herself directly to di Manes, who are, just as the Greek nekydaimones in (28), "mute and silent" or muti et taciti in (31).

Various animals form part of the simile formulae on four tablets (one Greek and three Latin, our Section III). These invariably aim to establish a connection between the manipulation of the animal and the victim (who should suffer the same effects that are caused by this manipulation). In (33) and (34), a Greek and a Latin curse from Carthage, the similes make use of the manipulation of a rooster. It is ritually bound in (33) to prevent the success of a chariot racer and his horses (who will not advance far, being bound as the rooster is), while in (34) the rooster's tongue is torn out and pierced through to prevent 
the capacity of speech from the writer's enemies in court (who will not be very effective orators, having their tongues torn out as the rooster's is). Another Latin curse made use of a puppy in two distinct ways - first, it sought to transfer one of its "natural" properties, namely "harmlessness" (35); second, in combination with an aversus formula, it is pierced through and the same should befall the writer's enemies (50). The simile in (36) is again used to silence enemies at court, who should become like "a frog without tongue" (rana sine lingua).

Small differences in the use of the simile formulae may be found in those cases in which the materiality of the tablet is being referred to (our Section I). There are 16 tablets in total (8 Greek, 8 Latin), with the Greek dated as early as the 5th cent. BCE. Most of the Greek tablets are from legal contexts, cf. (1), (2), (3), and possibly also (14) and (15), targeting the ability to think and speak. In the Latin documentation, prayers for justice $(6,7$, $9, \mathbf{1 6})$ are the most numerous, but we find also curses in legal contexts $(\mathbf{8})$ and separation spells (11). The simile formulae often make use of the physical properties of the tablet,




All of the parallels are used to silence opponents at court and their similarity points to a sustained use of this magical paradigm.

In Latin curses, there are very few references to the physical properties of lead, except for its considerable weight (pondus; 6). One analogy with the Greek examples cited above

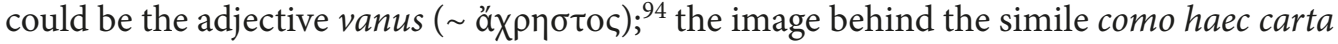

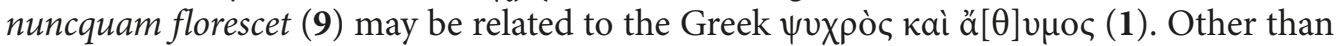
these closer or more distant analogies, Latin writers consistently refer to manipulation of the tablet - a feature found only in a single Greek simile (4) in which the tablet is buried in the depths and "separated" from human beings, as Zolios should be separated from Antheira, his well-being buried in the depths. A similar "descent" of a lead tablet into the underground is also found in the Latin similes (7) (decadet) and (8) (subsidet). Latin defixiones also feature a particular type of magical manipulation of the tablet, namely subjecting it to fire (sic illorum membra liquescan( $t$ ) quatmodum hoc plumbum liquescet, (9) $)^{95}$ - a practice also attested in the Greek material, see (10). The image of the "melting limbs" is also found in (44) from Mainz (et a (d qu)em modum sal in (aqua liques)cet, sic et illi membra $m($ ed)ullae extabescant), possibly connected also with (16), and the same idea is also found on (57).

Regarding persuasive analogies based on a mythological story or referencing a cult practice connected to some deity, also called historiolae, we have three Greek and seven Latin similes attested on nine tablets in total (our Section IV). Among the Greek similes, we find references to Greek (Hephaestus binding his own mother, (37)), Egyptian (the love of Isis for Osiris, (38)), and Hebrew (Yahweh striking down the pharaoh, (39)) mythology. In Latin texts, the magical powers of Minerva-Athena, Circe, and the Sirens (42) are mentioned as is a magical wand (virga deum inferum, 41 ) that punishes those who have practiced

93 Wishes for enemies to become mute are also attested in Latin, albeit often without an accompanying simile formula; see, e.g., DFX 5.1.2/1 (TheDeMa 739): ...ut F[r]onto fiat mutus...; DT 217 (TheDeMa 784): ...ne contra me nec dicere nec facere va[l]eant nisi quod ego voluero; al[li]go deligo linguas..., etc.

${ }_{94}$ LCT 71 (DFX 5.1.2/2): (Do i)nimicos Sexti, [...] ut sic (sint) vani et m(uti)...

95 According to Gordon 2012, 198, the inscribed tablet is subjected to flames and melted "so that its message passed 'into' the other world, the melting lead was thus a metonymy for the passing of the message. Those that survive for us to read are those that failed to be properly transmitted". 
iniquity and worked evil during their time on the face of the earth. Simile (40), a prayer for justice written by a victim of theft, fittingly introduces the story of the mythological thief par excellence Cacus. A special group of similes $(43,44,45,46)$ is attested from the sanctuary of Isis and Magna Mater in Mogontiacum (Mainz). These use as comparata the practices and rituals of the cult of these oriental deities and refer to the self-mutilation of the Galli and Bellonarii, the priests of Mater Magna (quomodo galli se secant et praecidunt vir(i)lia sua, (44); galli Bellonarive absciderunt concideruntve se, (45); sibi sanguin(em) ferventem fundunt, (44)). It is likely that these innovative features in the Latin curse tradition originated in a single magical workshop (or perhaps from a single mage?) operating in the area around modern Mainz in the 1st-2nd cent. CE, since all these tablets share a location and dating. To these tablets, we might add the recent find from Kempraten (13), which has also been found in the sanctuary of Mater Magna and is dated similarly.

Non-standard script orientation and aversus formulae (our Section V) are attested on 11 tablets in total (3 Greek and 8 Latin), usually non-specific curses or curses written in a legal context. The comparatum in these cases is a non-standard mode of writing and spelling - retrograde writing, letters written upside down, jumbled spelling, anagrams, special arrangements of the words and phrases on the tablet, etc. In the Greek documents,

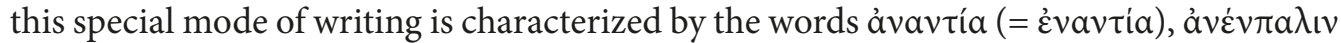
(= ع́ $\mu \pi \alpha \lambda ı v)$, and $\dot{\varepsilon} \pi \alpha \rho i ́ \sigma \tau \rho \rho$ in (47), (48), and (49), respectively. The magical analogy used in these instances is simple - just as the names of the victims or the text of the curse itself is written "upside down" or (quite literally) "in a sinister way", so should the well-being of the enemies be turned upside down and destroyed.

In the case of the Latin curses, we may differentiate two types of "twisting" - one makes reference to the non-standard orientation of the writing (as in the Greek examples); in the other, the subject of this "twisting" is not the script but the object that produces the script, namely a stylus. Latin tablets are attested mostly from Germania and Pannonia and dated to the 1st-3rd cent. CE. Simile formulae invariably use compounds of the verb vertere (avertere, pervertere etc.). The entire text is written in a non-standard way in similes (51) (perve( $r)$ se agas, comodo hoc perverse scriptu(m) est), (52), and (53). In (54), only the name of the victim is written upside down.

In three Latin defixiones, the simile with an aversus formula seems to be based on a manipulation of the stylus. In all three cases, the text is written in a standard way (and therefore there must have been another type of magical manipulation that served as the basis for the persuasive analogy); moreover, the recent archaeological findings of an intentionally crooked stylus unearthed near the tablet containing formula (55) (eo modo hoc ego averso graphio scribo, sic linguas illorum aversas ne pos(s)int facere contra) further corroborate this hypothesis. It is likely that the same procedure has been used in the preparation of the prayers for justice from Mogontiacum (Mainz) containing formulae (56) (grapphio averso, quod minime uti solet) and (57) (averse scribo). It is possible that this type of magical analogy was a Latin innovation, but the term graphium points to a Greek provenance of the magical prescription, although no Greek tablet with a simile of this type has survived in the archaeological record. An atypical aversus formula that involves not the orientation of the script but a puppy belongs here as well (50).

With respect to the use of "names" in simile formulae (our Section VI), there is a clear difference between Greek and Latin practice. In Greek, the term óvó $\mu a \tau a$ ("names") is attested in a series of tablets found in a well near the Athenian Agora and dated to the 3rd 
cent. CE, from which we chose 2 examples $(\mathbf{5 8}, \mathbf{5 9})$. The simile formulae in these invariably


kind of paralysis, should afflict the targets of the curse. These names, however, never denote the names of the victims, but rather the secret and powerful names of demons and deities written on the tablets. In contradistinction to this use, whenever Latin defixiones mention "name" (nomen) in a simile $(\mathbf{5 4}, \mathbf{5 5})$, it denotes the personal names of the victims.

Lastly, on three tablets (two Greek and one Latin) the persuasive analogy is based on drawings that accompany the curse text (our Section VII). On the verso side of the tablet containing simile (60), a drawing of Typhon-Seth is depicted as holding the victim by his hair. The heavy presence of "fiery" metaphors as well as the mention of the drawing itself being put in a fire suggest that the manipulation of this tablet involved this element in some shape or form, a practice also referenced by (9). Simile (61) makes use of a drawing of a mummified victim around whom two snakes are coiled. Finally, a Latin agonistic curse contains simile (62), which references the enemy being bound hand and foot.

A closer analysis of the corpus of simile formulae in Greek and Latin defixiones shows that the practice of employing these in cursing to facilitate or make possible intended magical operations has followed very closely a few well-established paradigms. Even though the pool of possible comparata for similes is theoretically inexhaustible, it seems that the performative use of similes in cursing was limited to only a handful of categories introduced and discussed in this paper. Notwithstanding some of the innovations mentioned above, the largely "conservative" approach to the similes indicates that the comparata believed to be "effective" in magical practice were fixed in writing (in magical prescriptions) and then consistently used over many centuries in time and across many thousands of miles in space, testifying to the robustness of the ancient Mediterranean magical koiné. Needless to say, the use of simile formulae is not limited to Greek and Latin documents but is also attested on artefacts of aggressive magic inscribed in Hebrew and Aramaic, ${ }^{96}$ Celtic, ${ }^{97}$ and Punic. ${ }^{98}$ The practice of sympathetic magic and the use of simile formulae

96 A bilingual Hebrew-Aramaic inscribed bowl contains a historiola that wishes for the victim to be destroyed like the Amalekites: "So shall the name of Judah, son of Nanay, be blotted out and [his memory] shall be uprooted from the world, just as the name of [Amalek] was blotted out ...", cf. Naveh - Shaked 1985, No. 9 (Gager 1992, No. 109, TheDeMa 174). Bohak 2008, 156-157, reported a remarkable erotic spell, dated to the 5th to 6th cent. CE, written originally on "a piece of unbaked clay which was then burned in a fire or kiln", which reads: "You ho[ly ...] angels, [I adjure] you, just as [this sherd burns, so shall] the heart of R[achel? daughter of Mar?] in burn after me, I [X son of Y] ...”. In the Greek and Latin curses and spells cited here, the metaphors of fire are of a more destructive nature - cf. our (9), (10), and (60). In the Hebrew spell, they are supposed to kindle desire in the practitioner's love interest. Greek and Latin tablets citing fire in connection with erotic magic are common, but we have no attestation of such a metaphor in simile formulae. Bar-Ilan 2002 collected further examples of sympathetic magic in the Mishnah and Talmud, albeit not of a performative kind.

97 See esp. the Larzac curse, aimed at silencing the opponents of the petitioner in a judicial context, quite like our (55). For an edition, translation, and ample commentary, cf. Mees 2009, 50-69: "[Just a]s she is holding their mouths tied so (too) are their mouths no[t be] earing judgment on anyone when they are bound by it (the enchantment) of the infernal one." (ibid., 64).

98 Cf., e.g., Müller 2000 and his interpretation of the Punic defixio KAI 89, similar to the Greek and Latin curses referencing the melting of lead, such as (9), (10), and (60): "Herrin Hwt (Lebendige), Göttin! Ein (Zauber-)Werk, das gegossen (geschmolzen) wurde, (ist) dies. Ich binde, ich, Mslḥ, den/die 'm [š]trt und die 'mrt und alles, was ihr gehört (oder: jeden, der ihr zugehört); denn sie lachten über mich wegen des Geldes, das ich eingebüßt habe (5) [ ]? oder (?) jeden Menschen, der über mich lacht wegen der Einbuße dieses Geldes. (Er sei,) wie Blei hingegossen (geschmolzen) wird" (ibid., 402). 


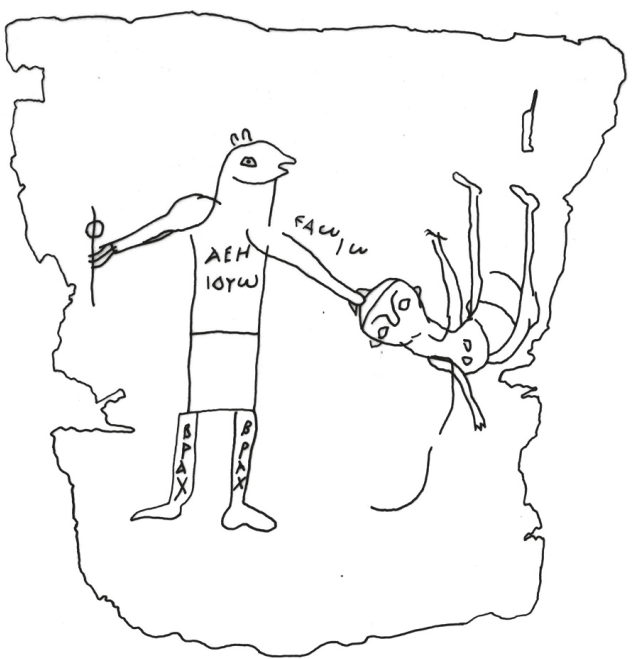

Fig. 1. Facsimile on the basis of Kantzia (1997) by Lucie Urbanová.

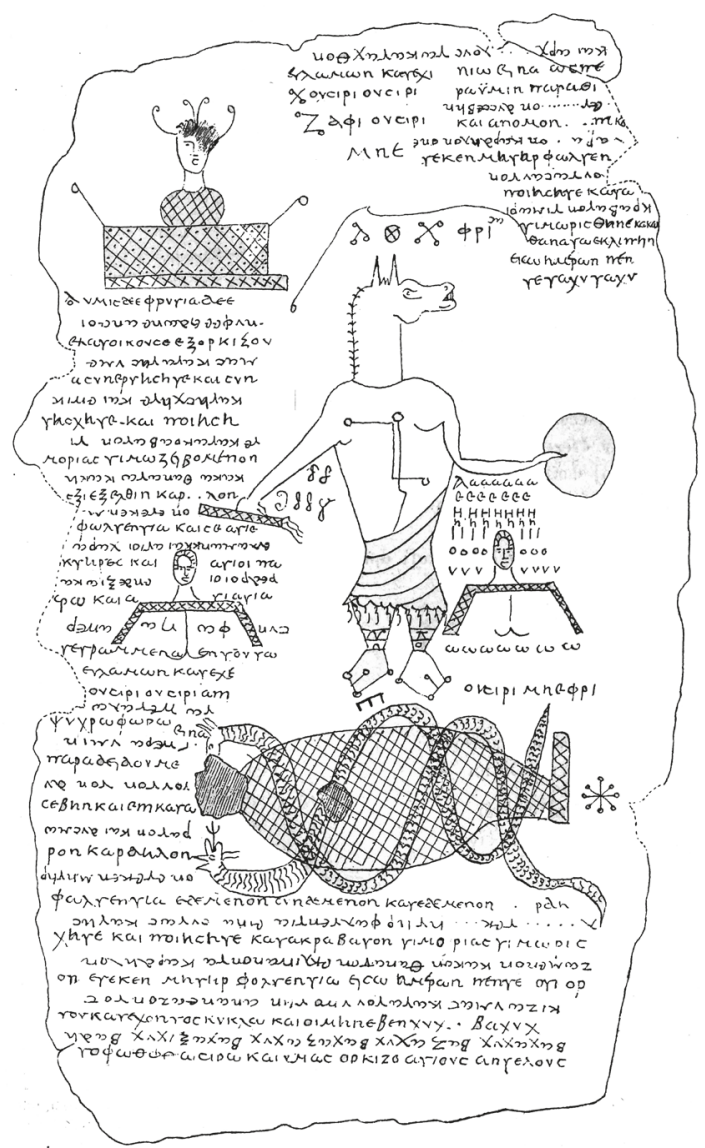

Fig. 2. Reproduced after Wünsch (1898) 


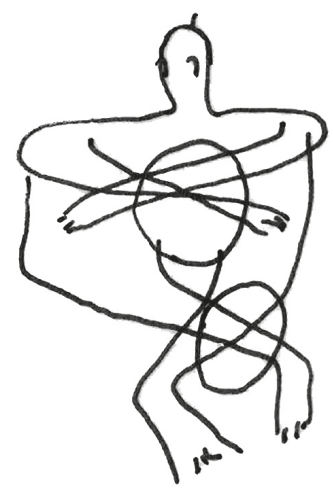

Fig. 3. Facsimile on the basis of Jordan (1988) by Lucie Urbanová

can therefore be considered as a widespread, cross-cultural universal practice of the Mediterranean oikov $\mu \dot{\varepsilon} v \eta$ during the entire period of antiquity.

\author{
Abbreviations \\ $\mathrm{BE}$ \\ DFX \\ DT \\ DTM \\ EBGR \\ ID \\ IG \\ LCT \\ PGM \\ SEG \\ SGD \\ SupplMag \\ TheDeMa \\ Bulletin épigraphique \\ Kropp, Defixiones: Ein aktuelles corpus lateinischer Fluchtafeln \\ Audollent, Defixionum Tabellae \\ Blänsdorf, Defixionum Tabellae Mogontiacenses \\ Epigraphic Bulletin for Greek Religion \\ Inscriptions de Délos \\ Inscriptiones Graecae \\ Urbanová, Latin Curse Tablets of the Roman Empire \\ Preisendanz, Papyri Graecae Magicae \\ Supplementum Epigraphicum Graecum \\ Jordan, A Survey of Greek Defixiones Not Included in the Special Corpora \\ Daniel - Maltomini, Supplementum Magicum \\ Thesaurus Defixionum Magdeburgensis
}

\title{
References
}

Alvar J. Romanising Oriental Gods: Myth, Salvation and Ethics in the Cults of Cybele, Isis and Mithras. Leiden - Boston, Brill, 2008.

Assmann J. Death and Salvation in Ancient Egypt. Ithaca \& London, Cornell University Press, 2005.

Audollent A. Defixionum tabellae. Paris, Albert Fontemoing, 1904.

Bailliot M. Roman Magic Figurines from the Western Provinces of the Roman Empire: An Archaeological Survey. Britannia 2015, 46, 93-110.

Bar-Ilan M. Between Magic and Religion: Sympathetic Magic in the World of the Sages of the Mishnah and Talmud. Review of Rabbinic Judaism 2002, 5 (3), 383-399.

Barta A. The Language of Latin Curse Tablets from Pannonia: A New Curse Tablet from Aquincum. AAntHung 2009, 49, 23-29.

Barta A. (in print) Some Remarks on The Latin Curse Tablets from Pannonia, in: Proceedings of the 13th International Colloquium on Vulgar and Late Latin: Latin vulgaire - latin tardif XIII (Budapest, 2018) $=$ AAntHung 2019, 59 . 
Barta A., Lassányi G. Az elgörbült nyelv: Új adatok egy aquincumi átoktábla rítusához. Ókor 2015, 1-2, $70-74$.

Betz H. D. (ed.) The Greek Magical Papyri in Translation, Including the Demotic Spells. Chicago - London, The University of Chicago Press, 1986

Bevilacqua G. Aurora, Orchi soror. PP 2009, 364, 47-70.

Bevilacqua G. Esseri rapitori e divinità femminili vendicatrici: Nuovi aspetti del mondo infero dal pantheon delle defixiones. SMSR 2010, 76 (1), 77-99.

Bevilacqua G., Colacicchi O. Una nuova defixio latina dalla via Ostiense. NSA, 2009, Ser. IX, 17-18, 303-349.

Blänsdorf J. The Defixiones from the Sanctuary of Isis and Mater Magna in Mainz, in: R.L.Gordon, F. M. Simón (eds). Magical Practice in the Latin West: Papers from the International Conference held at the University of Zaragoza, 30th Sept. - 1st Oct. 2005. Leiden, Brill, 2010, 141-190.

Blänsdorf J. Die defixionum tabellae des Mainzer Isis- und Mater Magna-Heiligtums: Defixionum tabellae Mogontiacenses. Mainz, Generaldirektion Kulturelles Erbe Rheinland-Pfalz, Direktion Landes-archäologie Mainz, 2012.

Blänsdorf J. "Ich bitte dich, Herrin Mater Magna, dass du mich rächst", in: C. Hattler (ed.). Imperium der Götter, Isis, Mithras, Christus: Kulte und Religionen im römischen Reich. Stuttgart, Konrad Theiss Verlag, 2013, 122-123.

Blänsdorf J. Das Verfluchtungstäfelchen von Gelubda (Gellep bei Krefeld) Grab 5486. ZPE 2014, 192, 181187.

Blänsdorf J., Kropp A., Scholz M. (2010). 'Perverse agas, comodo hoc perverse scriptu(m) est' - ein Fluchtäfelchen aus Köln. ZPE 2010, 174, 272-276.

Bohak G. Ancient Jewish Magic: A History. Cambridge: CUP 2008.

Curbera J. Six Boeotian Curse Tablets. ZPE 2017, 204, 141-158.

Curbera J., Papakonstantinou Z.Six Legal Curse Tablets from Athens, in: W. Riess (ed.) Colloquia Attica: Neuere Forschungen zur Archaik, zum athenischen Recht und zur Magie. Stuttgart, Steiner, 2018, 211224.

Daniel R. W., Maltomini F. Supplementum Magicum, Vol.II. Opladen, Westdeutscher Verlag, 1992.

Delatte A.L. Inscriptions imprécatoires trouvées à Carthage. BCH 1888, 12 (1), 294-302.

Dieleman J. Priests, Tongues, and Rites: The London-Leiden Magical Manuscripts and Translation in Egyptian Ritual (100-300 CE). Leiden - Boston, Brill, 2005.

Dubosson-Sbriglione L. Le culte de la Mère des dieux dans l'Empire romain. Stuttgart, Franz Steiner Verlag, 2018 (Postdamer Altertumswissenschaftliche Beiträge 62).

Egger R. Liebeszauber, in: A. Betz, G. Moro (eds). Römische Antike und frühes Christentum: Ausgewählte Schriften von R. Egger, Band II. Klagenfurt, Verlag des Geschichtsvereins für Kärnten, 1963, 24-33.

Egger, R. Nordtirols älteste Handschrift. Wien, Böhlaus, 1964 (Sitzungsberichte: Österreichische Akademie der Wissenschaften, Philosophisch-historische Klasse, Bd. 244, Abh. 1).

Eidinow E. Oracles, Curses, and Risk among the Ancient Greeks. Oxford, OUP, 2007.

Elderkin G. W. An Athenian Maledictory Inscription on Lead. Hesperia 1936, 5 (1), 43-49.

Elderkin G. W. Two Curse Inscriptions. Hesperia 1937, 6 (3), 382-395.

Faraone C. A., Kropp A. Inversion, Adversion and Perversion as Strategies in Latin Curse-Tablets, in: R.L.Gordon, F. M.Simón (eds). Magical Practice in the Latin West: Papers from the International Conference held at the University of Zaragoza, 30th Sept. - 1st Oct. 2005. Leiden, Brill, 2010, 381-398.

Franek J., Urbanová, D. 'May Their Limbs Melt, Just as This Lead Shall Melt...': Sympathetic Magic and the Similia Similibus Formula in Greek and Latin Curse Tablets (Part 1), Philologia Classica, 2019, 14 (1), 27-55.

Frankfurter D. Narrating Power: The Theory and Practice of the Magical Historiola in Ritual Spells, in: M. Meyer, P. Mirecky (eds.). Ancient Magic and Ritual Power. Leiden, Brill, 1995, 457-476.

Franz L. Ein Fluchtäfelchen aus Veldidena. JÖAI 1959, 54, 70-76.

Frei-Stolba R., Koch P., Lieb H. Eine neue Fluchtafel aus Kempraten (Kt. St. Gallen/CH), in: M. Scholz, M. Horster (eds.). Lesen und Schreiben in den Römischen Provinzen: Schriftliche Kommunikation im Alltagsleben. Akten des 2. Internationalen Kolloquiums von DUCTUS - Association internationale pour létude des inscriptions mineures, RGZM Mainz, 15.-17. Juni 2011. Mainz, Verlag des Römisch-Germanischen Zentralmuseums 2015, 113-122.

Gager J. G. Curse Tablets and Binding Spells form the Ancient World. New York - Oxford, OUP, 1992. 
Galsterer B. Das Bleitäfelchen aus Gellep Grab 5486, in: R. Pirling, M. Siepen (eds.). Das römisch-fränkische Gräberfeld von Krefeld-Gellep 1983-1988. Stuttgart, Steiner, 2000, 32-39.

Gordon R. "Ut tu me vindices": Mater Magna and Attis in Some New Latin Curse-Texts, in: A. Mastrocinque, C. Giuffrè Scibona (eds.). Demeter, Isis, Vesta and Cybele: Studies in Greek and Roman Religion in Honour of Giulia Sfameni Gasparro. Stuttgart, Franz Steiner Verlag, 2012, 195-212 (Potsdamer Altertums-wissenschaftliche Beiträge, 36).

Gordon R. Queering Their Pitch: The Curse-Tablets from Mainz, with Some Thoughts on Practicing Magic. JRA 2014, 27, 774-784.

Gordon R. Getting it Right: Performative Images in Greco-Egyptian Magical Practice, in: M. Arnhold, H. O. Maier, J. Rüpke (eds). Seeing the God: Image, Space, Performance, and Vision in the Religion of the Roman Empire. Tübingen, Mohr Siebeck, 2018, 101-123.

Gordon R. Imaginative Force and Verbal Energy in Latin Curse-Tablets, in: C. Sánchez Natalías (ed.). Litterae Magicae: Studies in Honour of Roger S. O. Tomlin. Zaragoza, Universidad de Zaragoza 2019, 111-130.

Griffiths J. G Plutarch's De Iside et Osiride. Cardiff, University of Wales Press, 1970.

Griffiths J. G. The Isis-Book (Metamorphoses, Book XI). Leiden, Brill, 1975.

Harari Y. Three Charms for Killing Adolf Hitler: Practical Kabbalah in WW2. Aries: Journal for the Study of Western Esotericism 2017, 17, 171-214.

Hard R. The Routledge Handbook of Greek Mythology. London — New York, Routledge, 2004.

Heintz F. Circus Curses and their Archaeological Contexts. JRA 1998, 11, 337-342.

Hollmann A. A Curse Tablet from Antioch against Babylas the Greengrocer. ZPE 2011, 177, 157-165.

Jevons F. B. Graeco-Italian Magic, in: R. R. Marett (ed.). Anthropology and the Classics. Oxford, Clarendon Press, 1908, 93-120.

Jordan D. R. A Curse Tablet from a Well in the Athenian Agora. ZPE 1975, 19, 245-248.

Jordan D.R. (a) A Survey of Greek Defixiones Not Included in the Special Corpora. GRBS 1985, 26 (2), 151-197.

Jordan D. R. (b) Defixiones from a Well Near the Southwest Corner of the Athenian Agora. Hesperia 1985, 54 (3), 205-255.

Jordan D. R. New Archaeological Evidence for the Practice of Magic in Classical Athens. Praktika tou XII diethnous synedriou klasikes archaiologias 1988, 4, 273-277.

Kalleres D. S. City of Demons: Violence, Ritual, and Christian Power in Late Antiquity. Oakland, CA, University of California Press, 2015.

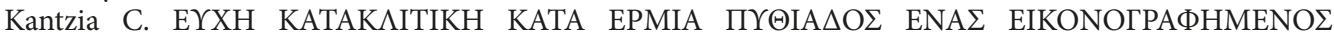

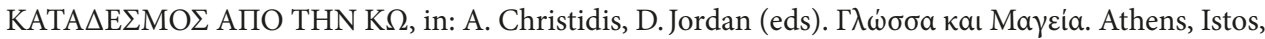
1997, 170-192.

Kitchell K. F. Animals of the Ancient World from A - Z. London - New York, Routledge, 2014.

Kropp A. Defixiones: Ein aktuelles Corpus lateinischer Fluchtafeln. Speyer, Kartoffeldruck-Verlag Kai Brodersen, 2008.

Lucarelli R. The Donkey in the Graeco-Egyptian Papyri, in: S. Crippa, M. Ciampini (eds). Languages, Objects, and the Transformations of Rituals: An Interdisciplinary Analysis on Ritual Practices in the GraecoEgyptian Papyri (PGM). Venezia, Edizioni Ca’ Foscari, 2017, 89-103.

Martín Hernández R. Reading Magical Drawings in the Greek Magical Papyri, in: P. Schubert (ed.). Actes du 26e Congrès international de papyrologie, Genève, 16-21 août 2010. Genève, Librairie Droz, 2012, 491-498.

Mees B. Celtic Curses. Woodbridge, The Boydell Press, 2009.

Müller H.-P. Die Tabella defixionis KAI 89 und die Magie des Fluchs. Orientalia 69 (4), 393-406.

Münsterberg R. Tri atičke ukletnje ploče. Glasnik Zemaljskog Muzeja u Bosni i Hercegovini 1901, 13 (1), 589-597.

Münsterberg R. Drei attische Fluchtafeln. Wissenschaftliche Mitteilungen aus Bosnien und der Herzegowina 1907, 10 (1), 375-377.

Naveh J., Shaked, S. Amulets and Magic Bowls: Aramaic Incantations of Late Antiquity. Jerusalem: Magnes Press, Hebrew University, 1985.

Ogden D. Animal Magic, in: G. L. Campbell (ed.). The Oxford Handbook of Animals in Classical Thought and Life. Oxford, Oxford University Press, 2014, 294-309.

Pachoumi E. The Concepts of the Divine in the Greek Magical Papyri. Tübingen, Mohr Siebeck, 2017. 
Petersmann H. Quam vim nomen in religionibus ac superstitionibus gentium habeat, in: B. Hessen (ed.). Lingua et Religio: Ausgewählte kleine Schriften zur antiken Religionsgeschichte auf sprachwissenschaftlicher Grundlage. Göttingen, Vandenhoeck \& Ruprecht 2002, 29-38.

Piranomonte M. Un contesto magico straordinario, in: M. Piranomonte - F. M. Simón (eds.). Contesti magici - Contextos mágicos. Roma, De Luca Editori d’Arte, 2012, 161-174.

Salayová A. Animals as Magical Ingredients in Greek Magical Papyri: Preliminary Statistical Analysis. GLB 2017, 22 (1), 191-206.

Salvo I. Sweet Revenge: Emotional Factors in 'Prayers for Justice', in: A. Chaniotis (ed.). Unveiling Emotions: Sources and Methods for the Study of Emotions in the Greek World. Stuttgart, Franz Steiner Verlag, 2012, 235-266.

Sánchez Natalías C. The Bologna Defixio(nes) revisited. ZPE 2011, 179, 201-217.

Sánchez Natalías C. Le defixiones durante la Tarda Antichità e la loro iconografia. Chaos e Kosmos 2013, 14, $1-19$.

Sánchez Natalías C. Magical Poppets in the Western Roman Empire: A Case Study from the Fountain of Anna Perenna, in: T. Minniyakhmetova, K. Velkobrodská (eds). Magic in Rituals and Rituals in Magic. Innsbruck - Tartu, ELM Scholarly Press, 2015, 194-202.

Scholz M. Verstummen soll er! Fluchtäfelchen wider Prozessgegner, in: M. Reuter - R. Schiavone (eds). Gefährliches Pflaster: Kriminalität im Römischen Reich. Mainz, Philipp von Zabern, 2011, 301-316.

Stylow A. U. Stumm wie ein Frosch ohne Zunge: Eine Fluchtafel aus Celti (Peñaflor, Prov. Sevilla). ZPE 2012, $181,149-155$.

Stylow A. U. ¡Mudo como rana sin lengua! Nueva tabella defixionis de Celti (Peñaflor, Sevilla), in: L. Alonso Alonso, M. Reyes Cilleza, M. Alfaro García (eds.). FARMM: Fondo Arqueológico Ricardo Marsal Monzón. Sevilla, Junta de Andalucía, Consejeía de Educación, Cultura y Deporte, 2014, 211-215.

Sutton D. The Greek Origin of the Cacus Myth. CQ 1977, 27 (2), 391-393.

Toynbee J. M. C. Animals in Roman Life and Art. Baltimore - London, The Johns Hopkins University Press, 1996.

Tremel J. Magica agonistica: Fluchtafeln im antiken Sport. Hildesheim, Weidmann, 2004.

Urbanová D. Alcune particolarità della comparazione (quomodo - sic, quemadmodum - sic, ita uti - sic) in latino volgare, con particolare attenzione alle defixiones. GLB 2016, 21 (2), 329-343.

Urbanová D. Latin Curse Texts: Mediterranean Tradition and Local Diversity. AAntHung 2017, 57, 57-82.

Urbanová D. The Latin Curse Tablets of the Roman Empire. Innsbruck, Institut für Sprachen und Literaturen der Universität Innsbruck, 2018.

Urbanová D. Between Syntax and Magic: Some Peculiarities of Nominal Syntax in Latin Curse Tablets, in: L.van Gils, C. Kroon, R. Risselada (eds.). Lemmata Linguistica Latina, vol. II: Clause and Discourse. Berlin, Walter de Gruyter, 2019, 620-639.

Urbanová D., Franek J. Il campo semantico di nomen nelle tavole defixionum, in: A. García Leal, C. E. Prieto Entrialgo (eds.). Latin Vulgaire - Latin Tardif XI: XI Congreso Internacional sobre el Latín Vulgar y Tardio (Oviedo, 1-5 de septiembre de 2014), Hildesheim - Zürich — New York, Olms - Weidmann, 2017, 616-628.

Urbanová D., Franek J. (in print) Hoc ego averse scribo: The Aversus-Formula on Ancient Greek and Latin Curse Tablets, in: O. Šefč́́k, H. Bichlmeier, R. Sukač (eds.). Etymologus: Festschrift für Václav Blažek. Hamburg, Baar-Verlag, 2019.

Urbanová D., Franek J., Barta A. (in print) Cursing in the Sanctuary: Some Textual Remarks on a Curse Tablet from Kempraten. Eirene 2019, 55.

Van der Horst P. W. Ancient Jewish Epitaphs: An Introductory Survey of a Millenium of Jewish Funerary Epigraphy (300 BCE - 700 CE). Kampen, Kok Pharos, 1991.

Van der Horst P. W., Newman, J. H. Early Jewish Prayers in Greek: A Commentary. Berlin - New York, Walter de Gruyter, 2008.

Versnel H.S. Beyond Cursing: The Appeal to Justice in Judicial Prayers, in: C. A. Faraone, D. Obbink (eds.). Magika Hiera: Ancient Greek Magic and Religion. Oxford: OUP, 1991, 60-106.

Viglione A. Le immagini figurate nei documenti magici, in: G. Bevilacqua (ed.). Scrittura e magia: Un repertorio di oggetti inscritti della magia greco-romana. Roma, Edizioni Quasar, 2010, 110-131.

Waller D. J. Echo and the Historiola: Theorizing the Narrative Incantation. Archiv für Religionsgeschichte 2015, 16 (1), 263-279. 
Weber E. Das Bleitäfelchen mit einem Liebeszauber aus Mautern an der Donau, in: L. Mikoletzky (ed.). Bericht über den Sechzehnten Österreichischen Historikertag in Krems/Donau. Wien: Verband Österreichischer Geschichtsvereine, 1985, 62-65.

West N. Gods on Small Things: Egyptian Monumental Iconography on Late Antique Magical Gems and the Greek and Demotic Magical Papyri. Pallas 2011, 86, 135-166.

White D. The Eschatological Connection between Lead and Ropes as Reflected in a Roman Imperial Period Coffin in Philadelphia. IEJ 1999, 49 (1-2), 66-91.

Wilburn A. T. Materia Magica: The Archaeology of Magic in Roman Egypt, Cyprus, and Spain. Ann Arbor, The University of Michigan Press, 2012.

Wortmann D. Neue magische Texte. BJ 1968, 168 (1), 56-111.

Wünsch R. Sethianische Verfluchungstafeln aus Rom. Leipzig, B. G. Teubner, 1898.

Wünsch R. Antike Fluchtafeln. Bonn, A. Marcus und E. Weber's Verlag, 1912.

Received: September 12, 2019

Accepted: October 27, 2019 